\title{
Quantitative ethnobotany of palms (Arecaceae) in New Guinea
}

\author{
Z. Dennehy ${ }^{1} \&$ R. Cámara-Leret ${ }^{2,3}$ \\ ${ }^{1}$ School of Biological Sciences, University of Reading, \\ Whiteknights, Reading, RG6 6AS, UK \\ ${ }^{2}$ Department of Evolutionary Biology and Environmental Studies \\ University of Zurich, 8057 Zurich, Switzerland \\ rodrigo.camaraleret@ieu.uzh.ch \\ ${ }^{3}$ Bren School of Environmental Science \& Management, University of California, \\ Santa Barbara, Santa Barbara, CA 93106-5131, USA
}

\begin{abstract}
We conducted a bibliographic review of palm use in New Guinea to quantify palm-utilisation patterns across the region's habitats, countries, and indigenous groups, and to identify the most useful species. We reviewed 187 bibliographic references and 140 herbarium specimens, spanning the years 1885-2018. We found 1178 use-reports and 894 palm-uses for 119 palm species. Lowland tropical rainforest is the best-studied habitat, and Indonesian New Guinea and Papua New Guinea have each received similar research effort. Most palms are used for Utensils and tools, Construction and Human food, and the stem, leaf and fruit are the most utilised palm parts. Only 5\% of New Guinea's indigenous groups have been studied, and $<10$ use-reports are recorded for most of the indigenous groups studied. Important species included Actinorhytis calapparia H.Wendl. \& Drude, Adonidia maturbongsii W.J.Baker \& Heatubun, Areca catechu L., Areca macrocalyx Zipp. ex Blume, and Metroxylon sagu Rottb. Overall, our study highlights the importance of palms for fulfilling subsistence needs in New Guinea, indicates that palm ethnobotany is neglected in the world's most bioculturally diverse island, and gives directions for future research.
\end{abstract}

Keywords. Ecosystem services, indigenous societies, medicinal plants, traditional knowledge

\section{Introduction}

Palms (Arecaceae) are a highly diverse plant family with approximately 2600 species and 181 genera (Baker \& Dransfield, 2016). Widespread across the tropics and subtropics, palms commonly grow in wet, hot humid environments and exhibit a range of growth forms (Balslev et al., 2011). Palms are abundant and sometimes hyperdominant in tropical forests (ter Steege et al., 2013), and their fruits are pivotal in the diets of many frugivorous animals (Muñoz et al., 2019). Globally, palms are the third most important useful plant family for humans (Haynes \& McLaughlin, 2000; Johnson, 2011), with historical records of human palm use that date to 10,000 years ago in Africa and South America (Morcote-Ríos \& Bernal, 2001; Gruca et al., 2016). Palms are commonly reported as the most useful plant family for indigenous and non-indigenous tropical forest communities (Prance et al., 1987), owing to their multiplicity of uses in food, construction, utensils, medicines and ritual practices 
(Sosnowska \& Balslev, 2009; Johnson, 2011). Regionally, the use of palms has been reviewed in northwestern South America (Sosnowska \& Balslev, 2008; Macía et al., 2011; Paniagua-Zambrana et al., 2015), Africa (Gruca et al., 2015), and Madagascar (Gruca et al., 2016), but ethnobotanical reviews are missing in other important palm hotspots.

New Guinea is one of the most bioculturally diverse areas on Earth, supporting a flora of $>13,000$ plant species (Roos et al., 2004) and $>1100$ languages (Simons \& Fennig, 2018). With $\sim 286$ native palm species, New Guinea has a megadiverse palm flora, including well-known palms of cultural importance like the sagu, Metroxylon sagu Rottb. (Kjær et al., 2004). The co-occurrence of high biological and cultural diversity in New Guinea (Gorenflo et al., 2012) has likely led to high levels of ethnobotanical knowledge about palms, but so far, no systematic literature review has quantitatively investigated palm utilisation in the region. As a result, fundamental information is missing on which palm species are important in satisfying human needs such as food and medicine, on which indigenous groups utilise palms more intensely, or on which habitats offer greater potential to develop the region's green economy. These gaps in turn limit attaining alternative economic models that suit the unique conditions of the region, which is a priority for the region's governments to balance conservation and development (Cámara-Leret et al., 2019).

Here, we present the first quantitative review of palm use in New Guinea, based on a review of 187 bibliographic references and 140 herbarium specimens that contained ethnobotanical information. Specifically, we aim to: (a) compare palm use between different habitats and between Indonesian New Guinea (ING) and Papua New Guinea (PNG), (b) analyse palm use patterns between different ethnobotanical use categories and subcategories, (c) identify the most frequently utilised palm parts, (d) determine patterns of palm use between different indigenous groups, and (e) identify socio-economically important palm species to indigenous communities and across New Guinea's habitats.

\section{Materials \& methods}

\section{Study area}

We consider 'New Guinea' as the region including the main island and the surrounding islands which were previously connected to the mainland during the last glacial maximum, excluding the Solomon Islands and Moluccas (Fig. 1). We delimited it using the General Bathymetric Chart of the Oceans (http://www.gebco.net) to select areas $\geq-120 \mathrm{~m}$ depth. Thus, the study area corresponds with the Papuasia Floristic Region (Brummitt et al., 2001) and covers a latitudinal range of -0.08 to -10.66 and a longitudinal range of 129.42 to 150.21 . According to the classification of Paijmans (1976), New Guinea's habitats include mangrove forest, lowland peat swamp forest, lowland savannah, lowland tropical rain forest $(0-500 \mathrm{~m})$, lower montane forest (500$1500 \mathrm{~m})$, mid montane forest (1500-2800 m), upper montane forest (2800-3200 m), and subalpine forest and alpine grasslands $(>3200 \mathrm{~m})$. 


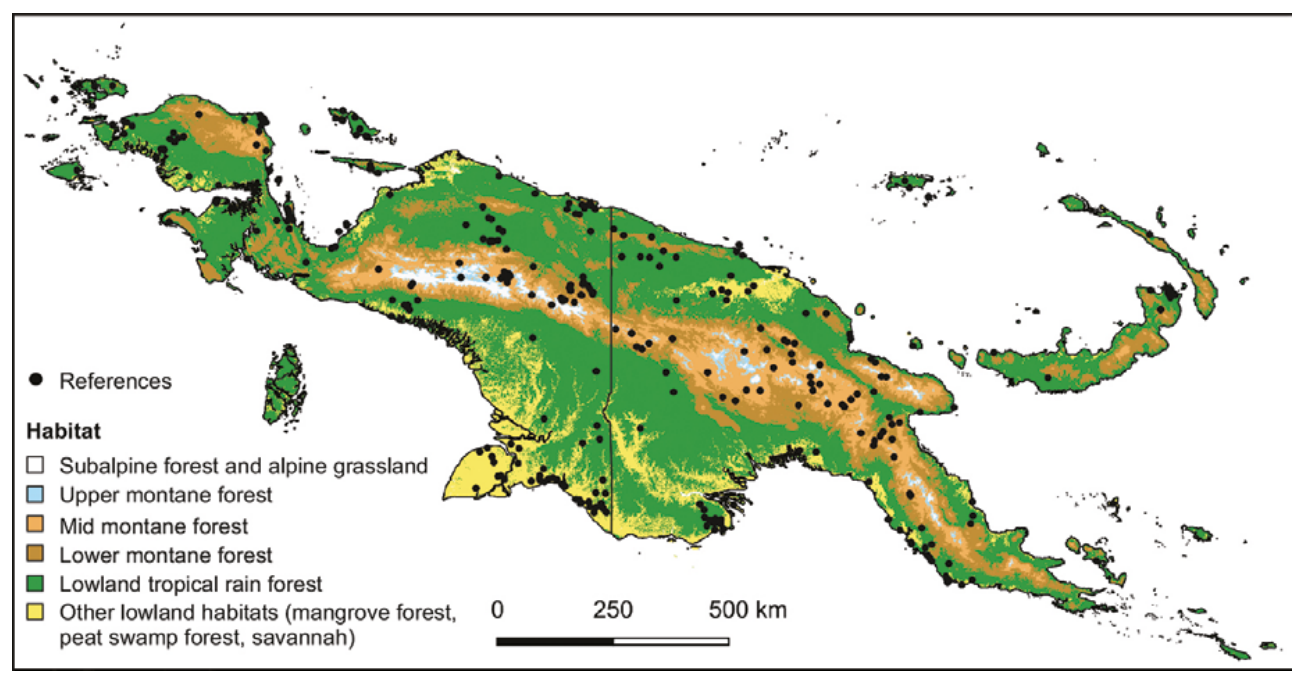

Fig. 1. Distribution of palm ethnobotanical research across New Guinea's habitats.

\section{Data collection}

We assembled palm ethnobotanical information by searching the Kew Bibliographic Database and Google Scholar using the following terms and their combination: Papua New Guinea, ethnobotany, food plants, medicine, New Guinea, timber, traditional use of plants and traditional medicinal plants. This search was supplemented with references cited in Hide's bibliographies of ethnobotanical research in West Papua (Hide 2014a, 2014b, 2015, 2016a, 2016b, 2017), references cited in Papuaweb (www. papuaweb.com) and with ethnobotanical information from the labels of 140 palm specimens deposited at $\mathrm{K}$ and $\mathrm{L}$. The search terms and sources combined resulted in a broad coverage with a total of 187 bibliographic references that were published in English $(n=135)$, Bahasa Indonesia $(n=49)$, French $(n=3)$, and German $(n=1)$. For a list of references and herbarium specimens consulted, see Supplementary Table 1.

\section{Data organisation}

When available, the name of the country, island, habitat, elevation, species scientific name, utilised plant part, indigenous group, locality and original plant use description was recorded for each bibliographic reference and herbarium specimen. Each plant use was assigned to one of ten use categories and associated subcategory according to the Economic Botany Data Collection Standard (Cook, 1995) with modifications explained in Cámara-Leret et al. (2014): Animal food, Human food, Construction, Culture, Environmental, Fuel, Medicinal and veterinary, Toxic, Utensils and tools, and Other uses. The subcategories Other-Environmental and Other-Toxic were created for plant uses which could not be classified under pre-existing use subcategories in Environmental and Toxic. Plant parts included the bark, bract, cirrus (a wire-like climbing structure that emerges from the rachis and is common amongst climbing palms), entire leaf, entire plant, exudates, flower, fruits, inflorescence, infructescence, 


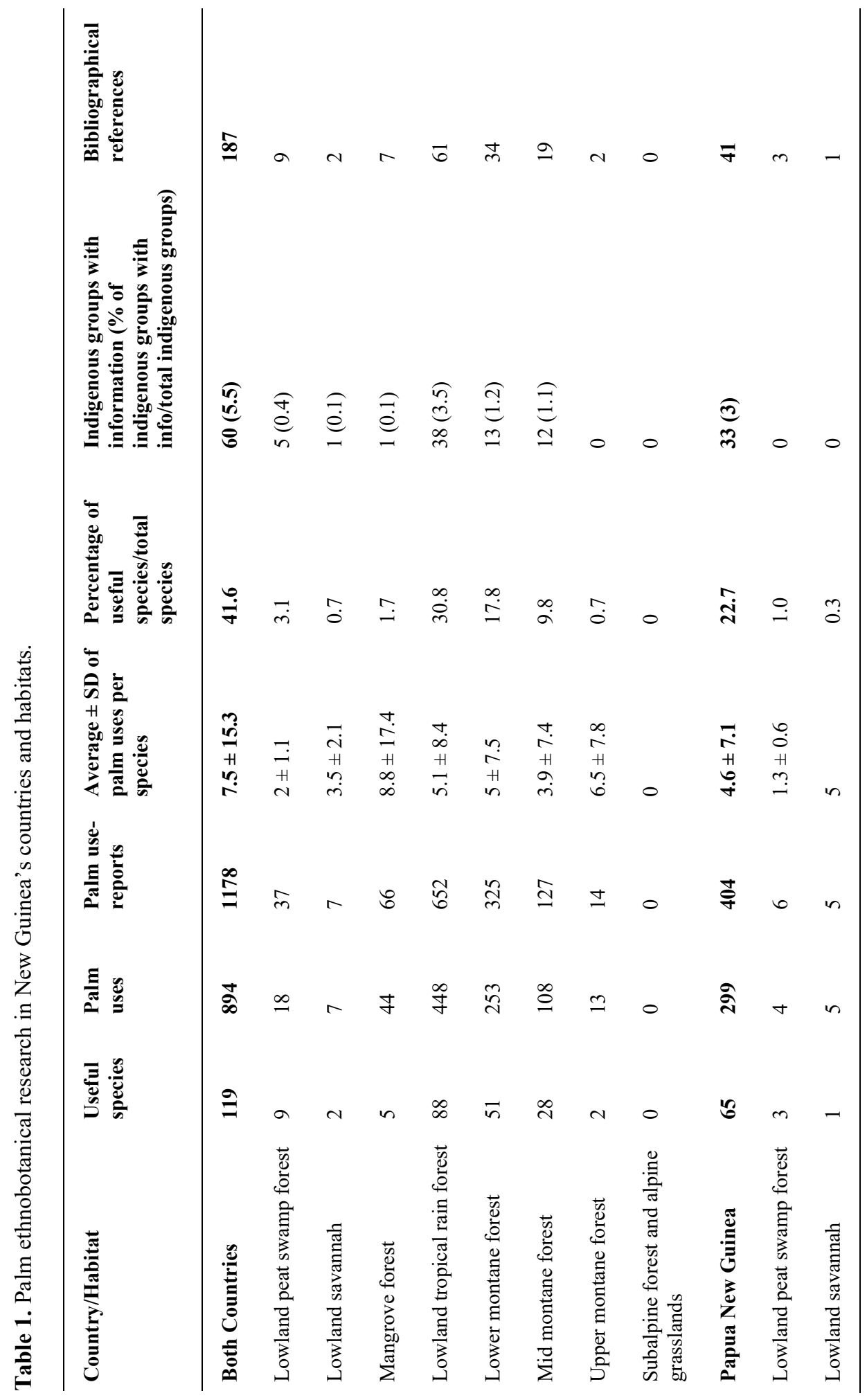




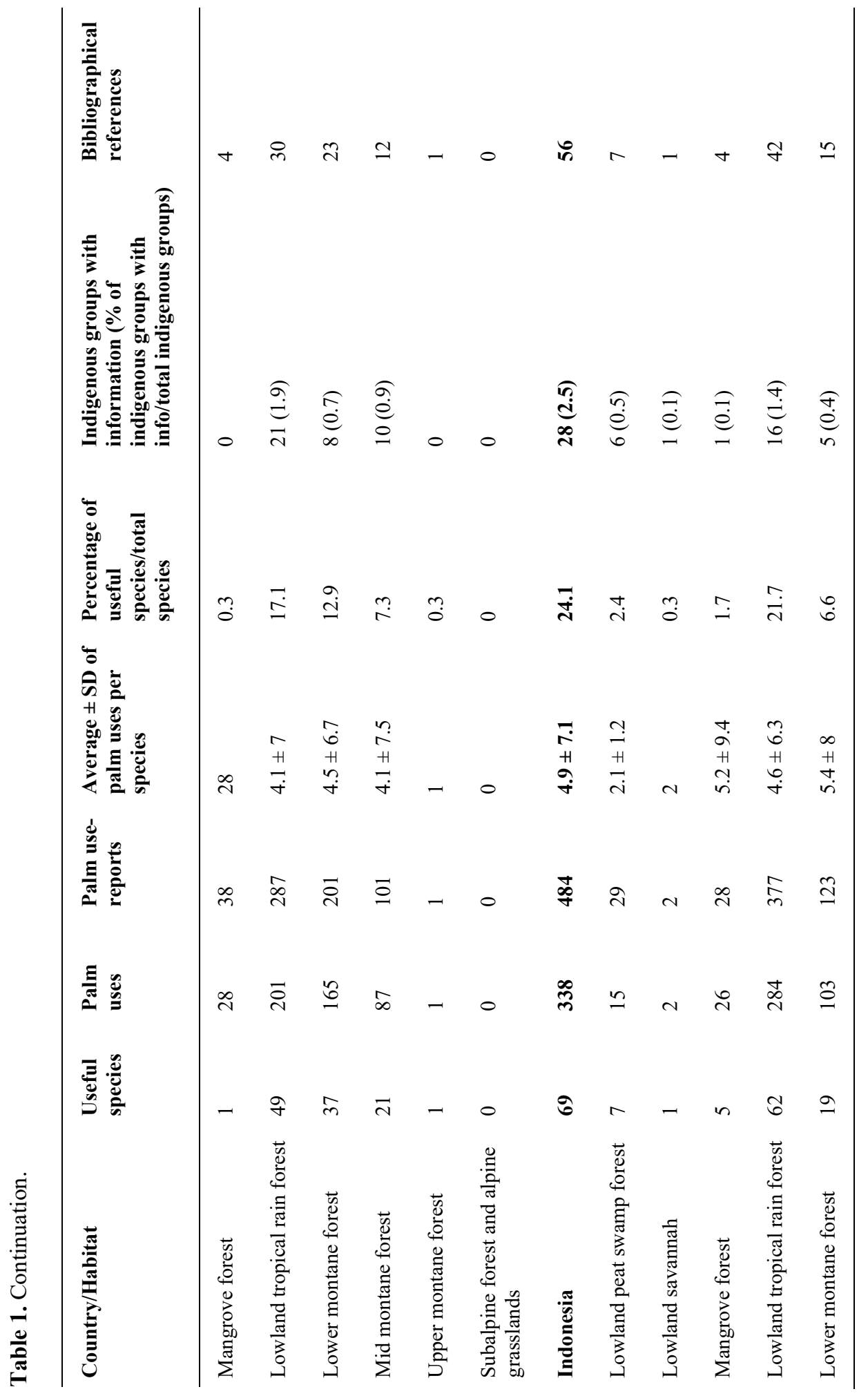




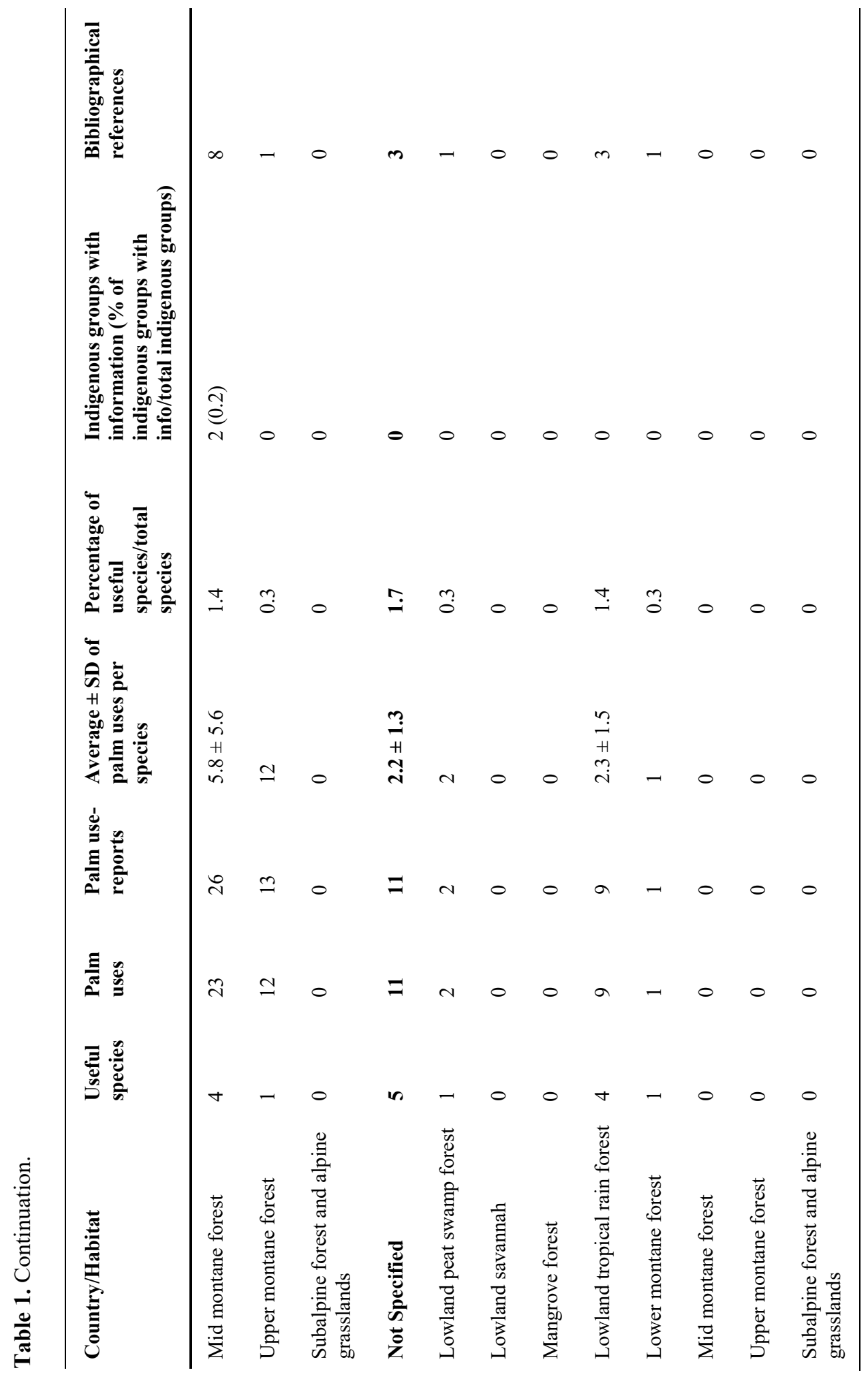


leaf rachis, leaf sheath, palm heart (apical meristem or cabbage), petiole, roots, seed, spear leaf, stem and young shoots. Plant parts which were unspecified were classified as 'Not specified'. Plant species nomenclature was unified using Plants of the World Online (http://powo.science.kew.org).

Indigenous group names were verified using either Glottolog (http://glottolog. org) or Ethnologue (www.ethnologue.com ). Indigenous group names which could not be verified were classified as 'Unresolved' and use-reports which did not have an associated indigenous group were classified as 'Unspecified'. The geographic location of each indigenous group was recorded from the literature. When coordinates were missing, the language ISO-639-3 code was obtained from Ethnologue or TransNewGuinea (http://transnewguinea.org) and matched with available coordinates in Glottolog.

\section{Data analyses}

We defined a 'plant use' as the use associated to a use category and subcategory for a specific plant part for a given species. A 'use-report' was defined as the citation of a 'plant use' from a bibliographic reference or herbarium specimen. All analyses were performed at the species level. Only use-reports with habitat information were utilised for quantifying patterns between habitats in New Guinea. We calculated the Relative Importance (RI) index to determine the most important useful species in each habitat. The maximum RI value is 2 and was calculated using the following equation: $\mathrm{RI}=$ NUC + NT, where NUC is the number of use categories of a species divided by the total number of use categories of the most versatile species, and NT is the number of use subcategories of a given species divided by the total number of use subcategories of the most versatile species.

\section{Results}

\section{Palm use by habitats and countries}

Overall, our review of 140 herbarium specimens and 187 bibliographical references published between 1885-2018 resulted in 1178 palm use-reports for 119 useful palm species ( $42 \%$ of New Guinea's palm species) and 894 palm uses (Table 1). The average number of palm uses per species was 7.5 \pm 15.3 . Indonesian New Guinea and PNG had a similar number of useful species (69 and 65), but ING had more palm uses (338 vs. 299), palm use-reports (484 vs. 404), and references (56 vs. 41). The average number of palm uses per species was similar between ING and PNG (4.9 \pm 7.1 vs. $4.6 \pm 7.1)$, and ING had fewer indigenous groups with information (28 vs. 33 in PNG). Below, we present information for each habitat:

\subsection{Mangrove forest}

Five useful palm species were recorded from seven references for this habitat, yielding 66 use-reports, 44 palm uses, and an average number of palm uses per species of $8.8( \pm$ 
17.4). For PNG, four bibliographic references yielded 38 palm use-reports, one useful species and 28 palm uses, but no indigenous groups were mentioned. In ING, four bibliographic references contained 28 use-reports, five useful species, 26 palm uses, and an average of $5.2 \pm 9.4$ uses per species. One indigenous group was reported in ING: Inanwatan (Table 4).

\subsection{Lowland peat swamp forest}

A total of nine useful species, 18 palm uses and 37 use-reports were recorded from nine bibliographical references in this habitat. The average number of palm uses per species was $2 \pm$ (1.1). In PNG, three bibliographic references had three useful palm species, four palm uses and six use-reports, and an average number of palm uses per species of $1.3 \pm 0.6$. In ING, seven bibliographic references yielded 29 palm usereports, seven useful palm species, 15 palm uses and an average of $2.1 \pm 1.2$ uses per species. Five indigenous groups were recorded for $\mathrm{ING}$, and no indigenous groups was recorded in PNG.

\subsection{Lowland savannah}

Both countries had one useful palm species. In PNG the number of palm uses and usereports was five, whilst in ING the number of palm uses and use-reports was two. One indigenous group was recorded in ING, the Muyu.

\subsection{Lowland tropical rain forest}

This habitat had the highest values for all variables: 88 useful palm species $(31 \%$ of all palm species in New Guinea), 652 use-reports, and 448 palm uses from 61 bibliographical references. The average number of palm uses per species was $5.1 \pm$ 8.4. In ING there were 62 useful species and 284 palm uses from 377 use-reports and 42 bibliographic references, with $4.6 \pm 6.3$ uses per species. In PNG, 30 bibliographic references contained 49 useful species, 201 palm uses, 287 palm use-reports and an average of $4.1 \pm 7$ uses per species. Ethnobotanical information was recorded for 38 indigenous groups, with more groups from PNG than ING (21 vs. 16).

\subsection{Lower montane forest}

This habitat had the second highest values for all variables, with 51 useful species, 253 palm uses, 325 use-reports and 34 references. The average number of palm uses per species was $5( \pm 7.5)$. There were 37 and 19 useful palms recorded in PNG and ING, respectively. In PNG, 165 palm uses and 201 use-reports were recorded from 23 references, with an average number of palm uses per species of $4.5( \pm 6.7)$, whereas in ING there were 103 palm uses, 123 use-reports and $5.4 \pm 8.0$ uses per species from 15 references. Palm uses were recorded for 13 indigenous groups, with more from PNG than ING (eight vs. five).

\subsection{Mid montane forest}

This habitat had 28 useful palm species, 108 palm uses and 127 use-reports according to 19 bibliographical references. The average number of palm uses per species was 
3.9 ( \pm 7.4).). In PNG, 12 bibliographic references yielded 21 useful palm species, 87 palm uses, 101 palm use-reports, and an average of 4.1 uses per species $( \pm 7.5)$. In ING eight bibliographic references contained four useful species, 23 palm uses, 26 usereports, and an average number of palm uses per species of $5.8( \pm 5.6)$. Ethnobotanical information was recorded for 12 indigenous groups (10 vs. two).

\subsection{Upper montane forest}

Only one useful palm species was recorded in this habitat in each country, from a total of two bibliographic references. A total of 13 palm uses and 14 use-reports were recorded, with an average of $6.5( \pm 7.8)$ palm uses per species. In PNG, one palm use-report was recorded, whilst 13 use-reports were recorded in ING. No indigenous groups were recorded in this habitat.

\section{Use categories and plant parts}

To determine the most cited use categories and subcategories, we calculated the total percentage of useful palm species in each category and subcategory relative to the total useful species registered for each habitat and country. The most cited use categories were Utensils and tools (55\%), Construction (50\%), and Human food (38\%). Toxic (5\%), Animal food (5\%), Other uses (6\%) and Fuel (6\%) had the fewest useful palm species in the literature. Nine use subcategories had no recorded uses across all ecoregions. All plant parts were cited in the bibliography, but $10 \%$ of recorded palm uses had no specified plant part. The stem was the most frequently utilised part $(30 \%)$, followed by the entire leaf (14\%) and the fruits (13\%). Four plant parts accounted for $<1 \%$ of recorded palm uses: the spear leaf $(0.2 \%)$, cirrus $(0.2 \%)$, flowers $(0.7 \%)$ and bract $(0.8 \%)$. Below, we present information for each use category:

\subsection{Animal food}

The most cited use was Wildlife attractants for hunting, accounting for $57 \%$ of species in this category (Table 2). In comparison, Fodder (29\%) and Fish bait (14\%) were less frequently used. The fruits were the most frequently cited palm part (54\%), followed by the stem and entire plant (17\% in both), entire leaf $(8 \%)$ and seeds (4\%) (Table 3$)$.

\subsection{Human food}

The number of useful palm species in this category for ING and PNG was similar, representing $39 \%$ and $42 \%$ of all useful species, respectively. A total of $85 \%$ of species recorded in Human Food were used for Food, 30\% for Beverages, 11\% as Food additives, and one species (2\%) was prepared as an Oil. The most commonly used palm parts were the fruits (18\%), palm heart (14\%) and stem (13\%).

\subsection{Construction}

The importance of palms for Construction was similar between PNG and ING, with $53 \%$ and $52 \%$ of all useful palm species for New Guinea, respectively. Most species in this use category (78\%) were used for Houses including materials for walls, flooring and temporary shelters. A total of $47 \%$ of palm species were used for Thatch. Other 
Table 2. Percentage of useful palm species recorded in each habitat and country, broken down by use categories and subcategories.

Abbreviations: LPSF - Lowland peat swamp forest; LS - Lowland savannah; MN - Mangroves; LTF - Lowland tropical rain forest; LMF - Lower montane forest; MMF - Mid montane forest; UMF - Upper montane forest; NS - Country not specified.

\begin{tabular}{|c|c|c|c|c|c|c|c|c|c|c|c|}
\hline \multirow{2}{*}{$\begin{array}{l}\text { Use category/ } \\
\text { Subcategory }\end{array}$} & \multirow[t]{2}{*}{ Total } & \multicolumn{7}{|c|}{ Habitat } & \multicolumn{3}{|c|}{ Country } \\
\hline & & LPSF & LS & MN & LTF & LMF & MMF & UMF & PNG & ING & NS \\
\hline Human Food & 38.7 & 55.6 & 100 & 60 & 43.2 & 35.3 & 43.5 & 50 & 42.1 & 39 & 40 \\
\hline Food & 84.8 & 100 & 100 & 100 & 81.6 & 94.4 & 100 & 100 & 93.8 & 83.3 & 100 \\
\hline Beverages & 30.4 & - & 50 & 33.3 & 34.2 & 27.8 & 10 & - & 21.9 & 36.7 & - \\
\hline Oils & 2.2 & - & - & - & 2.6 & 5.6 & - & - & 3.1 & - & - \\
\hline Food additives & 10.9 & - & - & 33.3 & 10.5 & 11.1 & - & - & 18.8 & 6.7 & - \\
\hline Utensils and Tools & 55.5 & 11.1 & - & 20 & 62.5 & 70.6 & 65.2 & 100 & 71.1 & 57.1 & 20 \\
\hline Domestic & 40.9 & - & - & 100 & 32.7 & 33.3 & 73.3 & 50 & 46.3 & 29.5 & 100 \\
\hline Hunting and fishing & 66.7 & - & - & 100 & 67.3 & 61.1 & 46.7 & 50 & 63 & 59.1 & - \\
\hline Labour tools & 16.7 & - & - & 100 & 12.7 & 19.4 & 20 & - & 18.5 & 9.1 & - \\
\hline Wrappers & 13.6 & - & - & - & 16.4 & 8.3 & - & - & 9.3 & 15.9 & - \\
\hline Rope & 33.3 & 100 & - & 100 & 34.5 & 36.1 & 20 & - & 33.3 & 36.4 & - \\
\hline Other & 3 & - & - & - & 3.6 & - & - & - & 5.6 & 4.5 & - \\
\hline Construction & 50.4 & 33.3 & $\mathbf{5 0}$ & 60 & $\mathbf{5 5 . 7}$ & 47.1 & 43.5 & 50 & 52.6 & 51.9 & 80 \\
\hline Thatch & 46.7 & 66.7 & - & 33.3 & 51.0 & 45.8 & 30 & 100 & 50 & 37.5 & 50 \\
\hline Houses & 78.3 & 33.3 & - & 33.3 & 75.5 & 70.8 & 90 & 100 & 67.5 & 85 & 75 \\
\hline Transportation & 8.3 & - & - & 66.7 & 6.1 & 8.3 & 10 & - & 10 & 7.5 & - \\
\hline Other & 13.3 & - & - & - & 16.3 & 29.2 & 30 & 100 & 20 & 12.5 & - \\
\hline Culture & 26.9 & 22.2 & - & 20 & 27.3 & 33.3 & 43.5 & - & 35.5 & 24.7 & 20 \\
\hline Ritual & 6.7 & - & - & - & 29.2 & 11.8 & 10 & - & 25.9 & 31.6 & - \\
\hline
\end{tabular}


Table 2. Continuation.

\begin{tabular}{|c|c|c|c|c|c|c|c|c|c|c|c|}
\hline \multirow{2}{*}{$\begin{array}{l}\text { Use category/ } \\
\text { Subcategory }\end{array}$} & \multirow[t]{2}{*}{ Total } & \multicolumn{7}{|c|}{ Habitat } & \multicolumn{3}{|c|}{ Country } \\
\hline & & LPSF & $\mathbf{L S}$ & MN & LTF & LMF & MMF & UMF & PNG & ING & NS \\
\hline Recreational & 71.9 & 100 & - & 100 & 83.3 & 76.5 & 70 & - & 66.7 & 84.2 & 100 \\
\hline $\begin{array}{l}\text { Personal } \\
\text { adornment }\end{array}$ & 9.4 & - & - & - & 8.3 & 5.9 & - & - & 11.1 & 15.8 & - \\
\hline $\begin{array}{l}\text { Cloth and } \\
\text { accessories }\end{array}$ & 25 & - & - & 100 & 16.7 & 11.8 & 20 & - & 44.4 & 21.1 & - \\
\hline Cosmetic & 6.3 & - & - & - & 4.2 & 11.8 & - & - & 3.7 & 5.3 & - \\
\hline Dyes & 6.3 & - & - & 100 & 4.2 & 5.9 & 10 & - & 11.1 & 5.3 & - \\
\hline Other & - & - & - & - & - & - & - & - & - & - & - \\
\hline Animal Food & 5.9 & - & - & 20 & 4.5 & 7.8 & 4.3 & - & 10.5 & 5.2 & - \\
\hline Wildlife attractant & 57.1 & - & - & 100 & 25 & 50 & 100 & - & 50 & 50 & - \\
\hline Fodder & 28.6 & - & - & - & 50 & 25 & - & - & 50 & 25 & - \\
\hline Bait & 14.3 & - & - & - & 25 & 25 & - & - & - & 25 & - \\
\hline $\begin{array}{l}\text { Medicinal and } \\
\text { Veterinary }\end{array}$ & 9.2 & - & - & 20 & 9.1 & 9.8 & 13.0 & - & 17.1 & 10.4 & - \\
\hline Digestive system & 36.4 & - & - & - & 50.0 & 20 & - & - & 30.8 & 37.5 & - \\
\hline $\begin{array}{l}\text { Respiratory } \\
\text { system }\end{array}$ & 27.3 & - & - & - & 12.5 & - & 66.7 & - & 46.2 & 12.5 & - \\
\hline $\begin{array}{l}\text { General ailments } \\
\text { with unspecified } \\
\text { symptoms }\end{array}$ & 27.3 & - & - & 100 & 25.0 & 20 & - & - & 30.8 & 25 & - \\
\hline $\begin{array}{l}\text { Infections and } \\
\text { infestations }\end{array}$ & 27.3 & - & - & - & 37.5 & 20 & - & - & 7.7 & 37.5 & - \\
\hline $\begin{array}{l}\text { Skin and } \\
\text { subcutaneous } \\
\text { tissue }\end{array}$ & 36.4 & - & - & - & 50.0 & 40 & - & - & 30.8 & 37.5 & - \\
\hline $\begin{array}{l}\text { Muscular-skeletal } \\
\text { system }\end{array}$ & 9.1 & - & - & - & 12.5 & 20 & - & - & 15.4 & - & - \\
\hline
\end{tabular}


Table 2. Continuation.

\begin{tabular}{|c|c|c|c|c|c|c|c|c|c|c|c|}
\hline \multirow{2}{*}{$\begin{array}{l}\text { Use category/ } \\
\text { Subcategory }\end{array}$} & \multirow[t]{2}{*}{ Total } & \multicolumn{7}{|c|}{ Habitat } & \multicolumn{3}{|c|}{ Country } \\
\hline & & LPSF & $\mathbf{L S}$ & MN & LTF & LMF & MMF & UMF & PNG & ING & NS \\
\hline Poisoning & 18.2 & - & - & - & 25.0 & - & - & - & 7.7 & 25 & - \\
\hline $\begin{array}{l}\text { Reproductive } \\
\text { system and } \\
\text { reproductive } \\
\text { health }\end{array}$ & 18.2 & - & - & 100 & 12.5 & - & - & - & 15.4 & 25 & - \\
\hline $\begin{array}{l}\text { Cultural diseases } \\
\text { and disorders }\end{array}$ & 9.1 & - & - & - & 12.5 & - & - & - & 7.7 & - & - \\
\hline $\begin{array}{l}\text { Blood and } \\
\text { cardio-vascular } \\
\text { system }\end{array}$ & - & - & - & - & - & - & - & - & - & - & - \\
\hline Urinary system & - & - & - & - & - & - & - & - & - & - & - \\
\hline $\begin{array}{l}\text { Pregnancy, birth } \\
\text { and puerperium }\end{array}$ & 9.1 & - & - & - & 12.5 & 20 & - & - & 15.4 & - & - \\
\hline Dental health & 27.3 & - & - & 100 & 25 & 20 & - & - & 30.8 & 12.5 & - \\
\hline $\begin{array}{l}\text { Endocrine } \\
\text { system }\end{array}$ & - & - & - & - & - & - & - & - & - & - & - \\
\hline $\begin{array}{l}\text { Nervous system } \\
\text { and mental } \\
\text { health }\end{array}$ & - & - & - & - & - & - & - & - & - & - & - \\
\hline $\begin{array}{l}\text { Metabolic } \\
\text { system and } \\
\text { nutrition }\end{array}$ & - & - & - & - & - & - & - & - & - & - & - \\
\hline Sensory system & 18.2 & - & - & - & 25 & 20 & 33.3 & - & 38.5 & 12.5 & - \\
\hline Veterinary & - & - & - & - & - & - & - & - & - & - & - \\
\hline Not specified & 9.1 & - & - & - & 12.5 & 20 & - & - & 30.8 & - & - \\
\hline Other & 27.3 & - & - & 100 & 25 & - & - & - & 15.4 & 25 & - \\
\hline $\begin{array}{l}\text { Environmental } \\
\text { Uses }\end{array}$ & 13.4 & 11.1 & - & - & 12.5 & 23.5 & 21.7 & 50 & 21.1 & 11.7 & 20 \\
\hline
\end{tabular}


Table 2. Continuation.

\begin{tabular}{|c|c|c|c|c|c|c|c|c|c|c|c|}
\hline \multirow{2}{*}{$\begin{array}{l}\text { Use category/ } \\
\text { Subcategory }\end{array}$} & \multirow[t]{2}{*}{ Total } & \multicolumn{7}{|c|}{ Habitat } & \multicolumn{3}{|c|}{ Country } \\
\hline & & LPSF & $\mathbf{L S}$ & MN & LTF & LMF & MMF & UMF & PNG & ING & NS \\
\hline Ornamental & 56.3 & 100 & - & - & 63.6 & 58.3 & 40 & - & 62.5 & 33.3 & 100 \\
\hline Agroforestry & - & - & - & - & - & - & - & - & - & - & - \\
\hline Fences & 56.3 & - & - & - & 54.5 & 50 & 80 & 100 & 37.5 & 77.8 & - \\
\hline $\begin{array}{l}\text { Soil } \\
\text { improvement }\end{array}$ & 12.5 & - & - & - & 18.2 & 16.7 & 20 & - & 6.3 & 14.3 & - \\
\hline Fuel & 6.7 & 11.1 & - & 20 & 8.0 & 9.8 & 8.7 & 50 & 6.6 & 9.1 & - \\
\hline Firewood & 87.5 & 100 & - & 100 & 85.7 & 60 & 50 & 100 & 80 & 85.7 & - \\
\hline Fire starter & 37.5 & - & - & - & 42.9 & 60 & 50 & - & 20 & 28.6 & - \\
\hline Lighting & 12.5 & - & - & - & 14.3 & 20 & - & - & 20 & 14.3 & - \\
\hline Other & - & - & - & - & - & - & - & - & - & - & - \\
\hline Toxic & 5 & - & - & - & 5.7 & 7.8 & - & - & 5.3 & 5.2 & 20 \\
\hline Fishing & 33.3 & - & - & - & 40 & 25 & - & - & 25 & 50 & - \\
\hline Other & 66.7 & - & - & - & 60 & 75 & - & - & 75 & 50 & 100 \\
\hline Other uses & 6.7 & 33.3 & - & - & 6.8 & 9.8 & 4.3 & 50 & 9.2 & 6.5 & - \\
\hline
\end{tabular}

uses, that only mentioned 'building' or 'construction' and prevented assignment to a particular subcategory, had $13 \%$ of palm species. The most cited palm parts were the stem ( $50 \%$ of use-reports), and leaves $(24 \%)$.

\subsection{Culture}

A total of $26 \%$ of all useful palm species were utilised for cultural uses, with PNG having $35 \%$ and ING having $24 \%$ of all species. Recreational was the most important subcategory, and was generally reported for the use of betel nut palm (Areca catechu L.) or its substitutes (e.g. A. macrocalyx Zipp. ex Blume). Other Recreational uses included musical instruments and toys. The second most important subcategory was Cloth and accessories (25\%) followed by Personal adornment (9\%). The most used palm parts were the fruits $(27 \%)$, the entire leaf $(24 \%)$, stem $(16 \%)$ and the seeds (11\%). 
Table 3. Percentage of use-reports for palm parts and use categories in New Guinea.

\begin{tabular}{|c|c|c|c|c|c|c|c|c|c|c|c|}
\hline 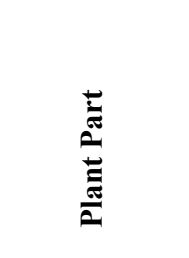 & 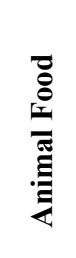 & 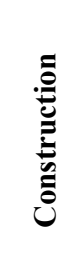 & $\stackrel{\stackrel{\Xi}{E}}{E}$ & 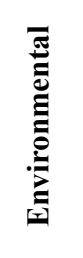 & 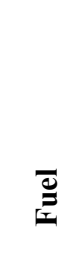 & 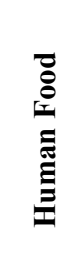 & 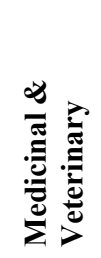 & $\stackrel{\dot{D}}{\dot{0}}$ & $\stackrel{\mathscr{X}}{e}$ & $\begin{array}{l}\frac{n}{8} \\
0 \\
0 \\
0 \\
0 \\
0 \\
0 \\
0 \\
0 \\
0\end{array}$ & స્ّ \\
\hline Bark & - & 3.6 & - & - & 4.3 & 0.6 & 1.7 & 5.6 & - & 1.3 & 1.6 \\
\hline Bract & - & 0.6 & 1.9 & - & - & - & - & - & - & 1.7 & 0.8 \\
\hline Cirrus & - & - & - & - & - & - & - & - & - & 0.9 & 0.2 \\
\hline Entire leaf & 8.3 & 24.4 & 23.6 & 6.3 & 8.7 & 6.5 & 7.8 & 5.6 & - & 13.9 & 14 \\
\hline Entire plant & 16.7 & 1.2 & 1.9 & 53.1 & - & - & 1.7 & 11.1 & - & 0.9 & 3.5 \\
\hline Exudates & - & - & - & - & 4.3 & 6.5 & 5.2 & - & 33.3 & - & 2.1 \\
\hline Flower & - & - & - & - & - & 3.0 & - & - & - & 0.4 & 0.7 \\
\hline Fruit & 54.2 & 0.6 & 27.4 & - & 8.7 & 18.5 & 27.8 & 16.7 & 33.3 & 1.3 & 13.5 \\
\hline Inflorescence & - & - & 0.9 & - & - & 6.5 & - & - & - & 0.9 & 1.6 \\
\hline Leaf rachis & - & 2.4 & 3.8 & 3.1 & 4.3 & - & 0.9 & - & - & 2.6 & 1.9 \\
\hline Leaf sheath & - & 1.8 & 0.9 & - & 4.3 & - & - & - & - & 5.7 & 2 \\
\hline Not specified & - & 10.7 & 8.5 & 3.1 & 8.7 & 7.1 & 10.4 & 16.7 & - & 16.1 & 10.5 \\
\hline Palm heart & - & - & - & - & - & 13.7 & - & - & - & - & 2.6 \\
\hline Petiole & - & 4.2 & 1.9 & 3.1 & 17.4 & 3 & - & - & - & 5.7 & 3.6 \\
\hline Root & - & - & 0.9 & - & - & 3.6 & 11.3 & - & - & 1.3 & 2.6 \\
\hline Seed & 4.2 & - & 11.3 & - & 4.3 & 7.1 & 7 & - & - & 3 & 4.6 \\
\hline Spear leaf & - & - & - & - & - & 1.2 & - & - & - & - & 0.2 \\
\hline Stem & 16.7 & 50 & 16 & 31.3 & 34.8 & 13.1 & 14.8 & 44.4 & 33.3 & 44.3 & 30.6 \\
\hline Young shoot & - & 0.6 & 0.9 & - & - & 9.5 & 11.3 & - & - & - & 3.5 \\
\hline
\end{tabular}




\subsection{Environmental}

The total percentage of useful palm species for this category was $13 \%$, with $21 \%$ of species in PNG and 12\% of species in ING. Most species in this category (56\%) were used as Ornamental or for Fences, 13\% were used as Soil improvement (fertilisers) and no palm species were recorded in Agroforestry. The most important plant parts were the entire plant (53\% of use-reports), the stem $(31 \%)$ and the entire leaf $(6 \%)$.

\subsection{Fuel}

The importance of palms for this category was similar between PNG and ING, with $7 \%$ and $9 \%$ of recorded palm species respectively. The most important use was for Firewood (88\%) and frequently used palm parts included the stem (35\%), petiole $(17 \%)$, entire leaves and fruits $(9 \%$ each).

\subsection{Medicinal and veterinary}

A total of $9 \%$ of the useful palm species in New Guinea were utilised for medicinal uses, with $17 \%$ of all useful species used medicinally in PNG and 10\% in ING. Digestive system (e.g. diarrhoea, dysentery and stomach pains) and Skin and subcutaneous tissue aliments (e.g. for tropical ulcers, sores and wounds) accounted for $36 \%$ of recorded medicinal species each. Five use subcategories accounted for $27 \%$ of useful palm species in this category. The most utilised plant parts for medicinal uses were the fruits $(28 \%)$, the stem $(15 \%)$ and roots and young shoots $(11 \%)$.

\subsection{Toxic}

Palm uses recorded under the Toxic category accounted for 5\% of all recorded palm species in PNG and ING. Of these, $>66 \%$ of species were classified under the Other subcategory, whilst 33\% were used for Fishing to either stun or kill fish. Three palm parts were utilised (fruits, stem and exudates), each accounting for $33 \%$ of recorded use-reports in this category.

\subsection{Utensils and tools}

Species used for Utensils and tools accounted for 55\% of all useful palm species in New Guinea, of which $57 \%$ of species were recorded for ING and 71\% for PNG. Most species in this category (67\%) were used for Hunting and fishing tools that included arrows, bows and spears. Next was Domestic utensils (41\%), followed by Rope (33\%), Labour tools (17\%), Wrappers (13\%) and Other uses (3\%). The most important palm parts used were the stem (44\%), entire leaf $(14 \%)$, leaf sheath $(6 \%)$ and petiole $(6 \%)$.

\subsection{Other uses.}

A total of $7 \%$ of useful palm species were recorded under Other uses. The percentage of species used in Other uses was similar between PNG (7\%) and ING (6\%). The predominant plant parts used were the stem (44\%), fruits (17\%) and the entire plant $(11 \%)$. Use of the bark and entire leaves accounted for $6 \%$ of recorded uses each. 


\section{Indigenous groups}

A total of 60 indigenous groups were recorded from 44 bibliographic references (Table 4). Of these, only 16 indigenous groups had $\geq 10$ recorded palm uses, 24 groups had $2-5$ uses and 18 groups had only one use. Fifteen indigenous groups were recorded in ING, 20 in PNG, and one (the Marind) was recorded in both countries. Lowland tropical rainforest had the highest number of indigenous groups with information (36), followed by lower montane and mid montane forest (13 and 12 indigenous groups, respectively), and no indigenous groups were recorded in the upper montane forest or in the subalpine forest and alpine grassland.

The Wandamen indigenous group of ING had the highest number of useful palm species (14) and the highest number of palm uses (55) and use-reports (59) from three bibliographic references in lowland tropical rain forest and lowland peat swamp forest habitats. In PNG, the best-documented group was the Mianmin, with 13 useful palm species, 19 palm uses and 20 use-reports from two bibliographic references.

\section{Important palm species by habitats}

According to the relative importance index (RI), Actinorhytis calapparia H.Wendl. \& Drude was the most important useful species in the lowland tropical rain forest, lower montane forest $(\mathrm{RI}=2.0 \mathrm{in}$ both), and mid montane forest (1.38), and it was the only species recorded with the maximum RI value (Table 5). Other important species included Adonidia maturbongsii W.J.Baker \& Heatubun in the lowland tropical rain forest $(\mathrm{RI}=1.76)$, Areca catech $(\mathrm{RI}=1.57)$ and Areca macrocalyx $(\mathrm{RI}=1.70)$. Areca macrocalyx had a total of 30 use-reports recorded in five use categories, with 19 use-reports in Recreational from the Culture use category, mostly related to the consumption of betel nut. Metroxylon sagu was the most important species in lowland savannah $(R I=0.29)$ and also in the upper montane forest $(R I=0.96)$ - where it is brought from the lowlands - with a total of 113 use-reports. Most reports were for Human food (50 reports for Food and one for Beverages) and Construction (23), while Other uses (12) and Utensils and tools (10) were less cited. Nypa fruticans Wurmb was the most important species in mangrove forest $(\mathrm{RI}=1.52)$, with 84 use-reports in seven use categories across all habitats. The most frequently recorded use category for Nypa fruticans was Human food (20 use-reports for Food, 10 for Beverages and two use-reports for Food additives). Other frequently recorded use categories for Nypa fruticans were Culture (17), Utensils and tools (15), Construction (13) and Medicinal and veterinary (5). Nypa fruticans was frequently cited for recreational purposes (as cigarette wrappers), for clothing and accessories, as roof thatching and for making alcoholic beverages.

Other important useful palm species included: 1) The non-native Arenga pinnata $($ Wurmb) Merr. $(\mathrm{RI}=1.11)$ with 41 recorded use-reports in all use categories; the most frequently recorded use categories being Utensils and tools (11 use-reports), Human food (8) and Construction (7);2) Caryota rumphiana Mart. (RI = 0.38), with 77 recorded use-reports (25 in Human food, 20 in Utensils and tools and 14 in Construction); and 3) Cocos nucifera $\mathrm{L}$. ( $\mathrm{RI}=0.38)$, with 71 use-reports from seven use categories, including Human food (28 use-reports), Medicinal and veterinary (16), and Utensils and tools (13). 
Table 4. Palm use by indigenous groups of New Guinea's habitats. Country abbreviations: I Indonesian New Guinea; P- Papua New Guinea.

\begin{tabular}{lcccccc}
\hline Indigenous Group & Country & $\begin{array}{c}\text { Useful } \\
\text { species }\end{array}$ & $\begin{array}{c}\text { Palm } \\
\text { uses }\end{array}$ & $\begin{array}{c}\text { Palm } \\
\text { use- } \\
\text { reports }\end{array}$ & $\begin{array}{c}\text { Uses } \pm \\
\text { SD per } \\
\text { species }\end{array}$ & References \\
\hline
\end{tabular}

Lowland peat swamp forest

$\begin{array}{lcccccc}\text { Kaiy } & \text { I } & 1 & 2 & 6 & 2 & 1 \\ \text { Papasena } & \text { I } & 3 & 4 & 4 & 1.3 \pm 0.6 & 1 \\ \text { Waigeo } & \text { I } & 1 & 2 & 2 & 2 & 1 \\ \text { Wandamen } & \text { I } & 1 & 1 & 1 & 1 & 1 \\ \text { Waritai } & \text { I } & 3 & 4 & 8 & 1.3 \pm 0.6 & 2\end{array}$

Lowland savannah

Muyu$$
\text { I }
$$

12

2

2

\section{Mangrove forest}

Inanwatan

I

2

4

4

$2 \pm 1.4$

\section{Lowland tropical rain forest}

\begin{tabular}{|c|c|c|c|c|c|c|}
\hline Amanab & $\mathrm{P}$ & 3 & 15 & 17 & $5 \pm 1$ & 1 \\
\hline Ambel & I & 3 & 3 & 3 & $1 \pm 0$ & 2 \\
\hline Amungme & I & 1 & 2 & 2 & 2 & 1 \\
\hline Awun & $\mathrm{P}$ & 1 & 1 & 1 & 1 & 1 \\
\hline Biak & I & 13 & 21 & 24 & $1.6 \pm 1$ & 4 \\
\hline Bongu & $\mathrm{P}$ & 3 & 6 & 6 & $2 \pm 1$ & 1 \\
\hline Bukawa & $\mathrm{P}$ & 1 & 2 & 2 & 2 & 1 \\
\hline Bulu & $\mathrm{P}$ & 1 & 1 & 1 & 1 & 1 \\
\hline Didipa & $\mathrm{P}$ & 2 & 5 & 5 & $2.5 \pm 0.7$ & 1 \\
\hline Gebe & I & 2 & 2 & 3 & $1 \pm 0$ & 2 \\
\hline Gidra & $\mathrm{P}$ & 1 & 1 & 2 & 2 & 2 \\
\hline Gnau & $\mathrm{P}$ & 1 & 1 & 1 & 1 & 1 \\
\hline
\end{tabular}


Table 4. Continuation.

\begin{tabular}{|c|c|c|c|c|c|c|}
\hline Indigenous Group & Country & $\begin{array}{c}\text { Useful } \\
\text { species }\end{array}$ & $\begin{array}{c}\text { Palm } \\
\text { uses }\end{array}$ & $\begin{array}{c}\text { Palm } \\
\text { use- } \\
\text { reports }\end{array}$ & $\begin{array}{l}\text { Uses } \pm \\
\text { SD per } \\
\text { species }\end{array}$ & References \\
\hline Grass Koiari & $P$ & 1 & 1 & 1 & 1 & 1 \\
\hline Iatmul & $\mathrm{P}$ & 1 & 1 & 1 & 1 & 1 \\
\hline Irarutu & I & 5 & 16 & 16 & $3.2 \pm 2.6$ & 1 \\
\hline Kairi & $P$ & 1 & 1 & 1 & 1 & 1 \\
\hline Kaulong & $\mathrm{P}$ & 1 & 1 & 1 & 1 & 1 \\
\hline Kwerba & I & 3 & 3 & 3 & $1 \pm 0$ & 1 \\
\hline Kwieftim & $\mathrm{P}$ & 1 & 1 & 1 & 1 & 1 \\
\hline Maibrat & I & 1 & 1 & 1 & 1 & 1 \\
\hline Marap & $\mathrm{P}$ & 2 & 3 & 4 & $1.5 \pm 0.7$ & 1 \\
\hline Marind & $\mathrm{I}, \mathrm{P}$ & 1 & 1 & 2 & 2 & 2 \\
\hline Meyah & I & 4 & 6 & 6 & $1.5 \pm 1$ & 1 \\
\hline Mianmin & $P$ & 1 & 3 & 3 & 3 & 1 \\
\hline Moi & I & 1 & 2 & 2 & 2 & 1 \\
\hline Nekgini & $\mathrm{P}$ & 1 & 2 & 2 & 2 & 1 \\
\hline Nokopo & $P$ & 1 & 1 & 1 & 1 & 1 \\
\hline Ormu & I & 8 & 21 & 21 & $2.6 \pm 1.3$ & 1 \\
\hline Patpatar & $P$ & 1 & 1 & 1 & 1 & 1 \\
\hline Saniyo-Hiyewe & $\mathrm{P}$ & 1 & 1 & 1 & 1 & 1 \\
\hline Supiori & I & 3 & 3 & 3 & $1 \pm 0$ & 1 \\
\hline Taburta & I & 1 & 2 & 2 & 2 & 1 \\
\hline Tepin & I & 6 & 13 & 15 & $2.2 \pm 1.9$ & 2 \\
\hline Wandamen & I & 13 & 54 & 58 & $4.2 \pm 3.8$ & 3 \\
\hline Yali & I & 1 & 5 & 5 & 5 & 1 \\
\hline Yimar & $\mathrm{P}$ & 1 & 1 & 1 & 1 & 1 \\
\hline
\end{tabular}


Table 4. Continuation.

\begin{tabular}{lcccccc}
\hline Indigenous Group & Country & $\begin{array}{c}\text { Useful } \\
\text { species }\end{array}$ & $\begin{array}{c}\text { Palm } \\
\text { uses }\end{array}$ & $\begin{array}{c}\text { Palm } \\
\text { use- } \\
\text { reports }\end{array}$ & $\begin{array}{c}\text { Uses } \pm \\
\text { Species }\end{array}$ & References \\
\hline
\end{tabular}

\section{Lower montane forest}

\begin{tabular}{|c|c|c|c|c|c|}
\hline Ambaidiru & I & 4 & 4 & 4 & $1 \pm 0$ \\
\hline Amungme & I & 2 & 3 & 3 & $1.5 \pm 0.7$ \\
\hline Didipa & $\mathrm{P}$ & 2 & 5 & 5 & $2.5 \pm 0.7$ \\
\hline Goilala & $\mathrm{P}$ & 1 & 3 & 3 & 3 \\
\hline Kukukuku & $\mathrm{P}$ & 1 & 1 & 1 & 1 \\
\hline Madik & I & 1 & 1 & 1 & 1 \\
\hline Menyamya & $\mathrm{P}$ & 1 & 1 & 1 & 1 \\
\hline Meyah & I & 3 & 5 & 5 & $1.7 \pm 0.6$ \\
\hline Mianmin & $\mathrm{P}$ & 8 & 8 & 8 & $2 \pm 1.2$ \\
\hline Nekgini & $\mathrm{P}$ & 1 & 2 & 2 & 2 \\
\hline Telefomin & $\mathrm{P}$ & 1 & 2 & 2 & 2 \\
\hline Tifalmin & $\mathrm{P}$ & 1 & 1 & 1 & 1 \\
\hline Yali & I & 4 & 10 & 12 & $2.5 \pm 1.3$ \\
\hline
\end{tabular}

\section{Mid montane forest}

\begin{tabular}{lcccccc} 
Dani & $\mathrm{I}$ & 1 & 9 & 10 & 9 & 2 \\
Enga & $\mathrm{P}$ & 1 & 1 & 1 & 1 & 1 \\
Huli & $\mathrm{P}$ & 1 & 1 & 1 & 1 & 1 \\
Kukukuku & $\mathrm{P}$ & 1 & 1 & 1 & 1 & 1 \\
Melpa & $\mathrm{P}$ & 3 & 3 & 3 & $1 \pm 0$ & 1 \\
Menyamya & $\mathrm{P}$ & 1 & 1 & 1 & 1 & 1 \\
Mianmin & $\mathrm{P}$ & 4 & 8 & 9 & $2 \pm 1.4$ & 1 \\
Pinai & $\mathrm{P}$ & 1 & 1 & 1 & 1 & 1 \\
Telefomin & $\mathrm{P}$ & 1 & 2 & 2 & 2 & 1 \\
\hline
\end{tabular}


Table 4. Continuation.

\begin{tabular}{lcccccc}
\hline Indigenous Group & Country & $\begin{array}{c}\text { Useful } \\
\text { species }\end{array}$ & $\begin{array}{c}\text { Palm } \\
\text { uses }\end{array}$ & $\begin{array}{c}\text { Palm } \\
\text { use- } \\
\text { reports }\end{array}$ & $\begin{array}{c}\text { Uses } \pm \\
\text { SD per } \\
\text { species }\end{array}$ & References \\
\hline Tifalmin & $\mathrm{P}$ & 1 & 1 & 1 & 1 & 1 \\
Wola & $\mathrm{P}$ & 8 & 18 & 18 & $2.3 \pm 0.9$ & 1 \\
Yali & $\mathrm{I}$ & 2 & 2 & 3 & $1 \pm 0$ & 1 \\
\hline
\end{tabular}

We found 23 useful palm species reported for the rattan genus Calamus L. The most common use categories for rattans were Utensils and tools (61 use-reports), Construction (24), Culture (10) and Human Food (10). Utensils and tools included uses for rope, hunting and fishing tools and for domestic uses, whereas Construction included uses for building houses, bridges and thatch. Seventeen Calamus species were recorded in lowland tropical rain forest, with $C$. bulubabi W.J.Baker \& J.Dransf. having the highest RI value (0.72), followed by $C$. humboldtianus Becc. (0.71) and C. barbatus Zipp. ex Blume (0.67). In the lower montane forest, 12 useful Calamus species were recorded, with $C$. anomalus Burret having the highest RI (0.81) followed by $C$. aruensis Becc. (0.67) and $C$. eximius Burret (0.63). In the mid montane forest, five useful Calamus species were recorded, with $C$. aruensis having the highest RI value (0.73). Calamus vestitus Becc. was the only Calamus species in the lowland peat swamp forest, and it had a RI value of 0.44 . The stem was the most frequently used palm part, representing $71 \%$ of use-reports in Calamus, followed by the entire leaf $(7 \%)$, exudates $(3 \%)$ and young shoots $(3 \%)$.

\section{Discussion}

The 119 useful palm species cited in 88 of the 187 reviewed bibliographic references represent $42 \%$ of New Guinea's palm species. This is a relatively low figure when compared to other tropical regions that have been better studied. For example, in northwestern South America, where palm ethnobotany has a long tradition, 194 species ( $63 \%$ of potential palm species) have been recorded as useful in 255 references (Macía et al., 2011). We found that the number of useful species and average number of palm uses were similar in ING and PNG, and that the average number of palm uses increased with number of bibliographic references. Given these results, and also because many areas lack ethnobotanical studies, we expect that further research efforts will significantly increase the number of palm uses for both countries in New Guinea (Fig. 1). 
Table 5. Relative Importance value (RI) of useful palms in New Guinea's habitats. Country abbreviations: I - Indonesian New Guinea; P - Papua New Guinea; N - Not specified

\begin{tabular}{|c|c|c|c|c|c|}
\hline Species per habitat & RI & $\begin{array}{l}\text { Palm } \\
\text { uses }\end{array}$ & $\begin{array}{c}\text { Palm } \\
\text { use- } \\
\text { reports }\end{array}$ & Countries & References \\
\hline \multicolumn{6}{|l|}{ Lowland peat swamp forest } \\
\hline Areca catechu $\mathrm{L}$. & 0.44 & 3 & 4 & I & 4 \\
\hline Calamus vestitus Becc. & 0.44 & 1 & 1 & I & 1 \\
\hline Cocos nucifera $\mathrm{L}$. & 0.29 & 2 & 4 & I & 2 \\
\hline Cyrtostachys renda Blume & 0.29 & 2 & 2 & $\mathrm{~N}$ & 1 \\
\hline Hydriastele costata F.M.Bailey & 0.29 & 1 & 1 & I & 1 \\
\hline Metroxylon sagu Rottb. & 0.15 & 3 & 15 & $\mathrm{I}, \mathrm{P}$ & 6 \\
\hline Metroxylon salomonense (Warb.) Becc. & 0.15 & 1 & 3 & $\mathrm{P}$ & 1 \\
\hline Nypa fruticans Wurmb & 0.15 & 4 & 6 & $\mathrm{I}, \mathrm{P}$ & 2 \\
\hline Orania regalis Zipp. & 0.15 & 1 & 1 & I & 1 \\
\hline \multicolumn{6}{|l|}{ Lowland savannah } \\
\hline Borassus flabellifer $\mathrm{L}$. & 0.19 & 5 & 5 & $\mathrm{P}$ & 1 \\
\hline Metroxylon sagu Rottb. & 0.29 & 2 & 2 & I & 1 \\
\hline \multicolumn{6}{|l|}{ Mangrove forest } \\
\hline Cocos nucifera $\mathrm{L}$. & 0.15 & 1 & 1 & I & 1 \\
\hline Livistona saribus (Lour.) Merr. ex A.Chev. & 0.15 & 1 & 1 & I & 1 \\
\hline Metroxylon sagu Rottb. & 0.15 & 1 & 1 & I & 1 \\
\hline Nypa fruticans Wurmb & 1.52 & 40 & 62 & $\mathrm{I}, \mathrm{P}$ & 6 \\
\hline Oncosperma tigillarium (Jack) Ridl. & 0.15 & 1 & 1 & I & 1 \\
\hline \multicolumn{6}{|l|}{ Lowland tropical rain forest } \\
\hline Actinorhytis calapparia H.Wendl. \& Drude & 2.00 & 8 & 9 & I & 2 \\
\hline Adonidia maturbongsii W.J.Baker \& Heatubun & 1.76 & 1 & 1 & I & 1 \\
\hline Areca catechu L. & 1.57 & 17 & 24 & I, P & 12 \\
\hline
\end{tabular}


Table 5. Continuation.

\begin{tabular}{|c|c|c|c|c|c|}
\hline Species per habitat & RI & $\begin{array}{c}\text { Palm } \\
\text { uses }\end{array}$ & $\begin{array}{c}\text { Palm } \\
\text { use- } \\
\text { reports }\end{array}$ & Countries & References \\
\hline Areca jokowi Heatubun & 1.15 & 1 & 1 & I & 1 \\
\hline Areca macrocalyx Zipp. ex Blume & 1.70 & 7 & 20 & $\mathrm{I}, \mathrm{P}$ & 7 \\
\hline Areca mandacanii Heatubun & 1.38 & 2 & 2 & I & 1 \\
\hline Areca novohibernica (Lauterb.) Becc. & 1.01 & 2 & 2 & $\mathrm{P}, \mathrm{N}$ & 2 \\
\hline Areca parens Becc. & 1.00 & 1 & 1 & I & 1 \\
\hline Areca unipa Heatubun & 1.05 & 2 & 2 & I & 2 \\
\hline Arenga listeri Becc. & 0.86 & 1 & 1 & I & 1 \\
\hline Arenga micrantha C.F.Wei & 0.67 & 1 & 1 & I & 1 \\
\hline Arenga microcarpa Becc. & 0.58 & 18 & 25 & I, P & 6 \\
\hline Arenga pinnata (Wurmb) Merr. & 0.63 & 37 & 41 & I & 4 \\
\hline Brassiophoenix schumannii (Becc.) Essig & 0.58 & 1 & 1 & $\mathrm{P}$ & 1 \\
\hline Calamus aruensis Becc. & 0.63 & 11 & 20 & $\mathrm{I}, \mathrm{P}$ & 5 \\
\hline Calamus barbatus Zipp. ex Blume & 0.67 & 1 & 3 & I & 1 \\
\hline Calamus bulubabi W.J.Baker \& J.Dransf. & 0.72 & 1 & 1 & I & 1 \\
\hline Calamus caesius Blume & 0.63 & 2 & 2 & I & 1 \\
\hline Calamus heteracanthus Zipp. ex Blume & 0.58 & 5 & 5 & I, P & 1 \\
\hline Calamus humboldtianus Becc. & 0.71 & 3 & 5 & $\mathrm{I}, \mathrm{P}$ & 2 \\
\hline $\begin{array}{l}\text { Calamus komsaryi (Maturb., J.Dransf. \& Mogea) } \\
\text { W.J.Baker }\end{array}$ & 0.53 & 2 & 3 & I & 1 \\
\hline Calamus longipinna K.Schum. \& Lauterb. & 0.48 & 2 & 3 & I, P & 2 \\
\hline $\begin{array}{l}\text { Calamus pachypus W.J.Baker, Bayton, J.Dransf. } \\
\& \text { Maturb. }\end{array}$ & 0.44 & 5 & 5 & I & 1 \\
\hline Calamus prattianus Becc. & 0.44 & 1 & 1 & I & 1 \\
\hline Calamus retroflexus J.Dransf. \& W.J.Baker & 0.53 & 2 & 2 & $\mathrm{P}$ & 1 \\
\hline Calamus schlechterianus Becc. & 0.44 & 1 & 1 & $\mathrm{P}$ & 1 \\
\hline
\end{tabular}


Table 5. Continuation.

\begin{tabular}{|c|c|c|c|c|c|}
\hline Species per habitat & RI & $\begin{array}{l}\text { Palm } \\
\text { uses }\end{array}$ & $\begin{array}{c}\text { Palm } \\
\text { use- } \\
\text { reports }\end{array}$ & Countries & References \\
\hline Calamus tenuis Roxb. & 0.48 & 1 & 1 & I & 1 \\
\hline Calamus vestitus Becc. & 0.29 & 4 & 7 & $\mathrm{I}, \mathrm{P}$ & 3 \\
\hline Calamus vitiensis Warb. ex Becc. & 0.34 & 5 & 7 & $\mathrm{I}, \mathrm{P}$ & 2 \\
\hline Calamus warburgii K.Schum. & 0.29 & 2 & 2 & $\mathrm{I}, \mathrm{P}$ & 2 \\
\hline Calamus zebrinus Becc. & 0.29 & 6 & 8 & $\mathrm{I}, \mathrm{P}$ & 4 \\
\hline Calyptrocalyx albertisianus Becc. & 0.29 & 1 & 1 & $\mathrm{P}$ & 1 \\
\hline Calyptrocalyx amoenus Dowe \& M.D.Ferrero & 0.34 & 2 & 2 & $\mathrm{P}$ & 1 \\
\hline Calyptrocalyx awa Dowe \& M.D.Ferrero & 0.34 & 1 & 1 & I & 1 \\
\hline Calyptrocalyx elegans Becc. & 0.34 & 3 & 3 & $\mathrm{P}$ & 1 \\
\hline $\begin{array}{l}\text { Calyptrocalyx merrillianus (Burret) Dowe \& } \\
\text { M.D.Ferrero }\end{array}$ & 0.29 & 2 & 2 & $\mathrm{P}$ & 1 \\
\hline Calyptrocalyx pachystachys Becc. & 0.34 & 1 & 1 & $\mathrm{P}$ & 1 \\
\hline Calyptrocalyx polyphyllus Becc. & 0.29 & 1 & 1 & $\mathrm{P}$ & 1 \\
\hline Calyptrocalyx yamutumene Dowe \& M.D.Ferrero & 0.34 & 1 & 1 & $\mathrm{P}$ & 1 \\
\hline Caryota rumphiana Mart. & 0.38 & 43 & 72 & $\mathrm{I}, \mathrm{P}$ & 16 \\
\hline Caryota urens $\mathrm{L}$. & 0.29 & 1 & 1 & I & 1 \\
\hline Cocos nucifera $\mathrm{L}$. & 0.34 & 42 & 63 & $\mathrm{I}, \mathrm{P}$ & 16 \\
\hline Corypha utan Lam. & 0.29 & 23 & 25 & $\mathrm{I}, \mathrm{P}$ & 2 \\
\hline Cyrtostachys excelsa Heatubun & 0.29 & 2 & 2 & I & 1 \\
\hline Cyrtostachys glauca H.E.Moore & 0.15 & 1 & 1 & $\mathrm{P}$ & 1 \\
\hline Cyrtostachys loriae Becc. & 0.15 & 4 & 9 & $\mathrm{I}, \mathrm{P}, \mathrm{N}$ & 3 \\
\hline Dransfieldia micrantha (Becc.) W.J.Baker \& Zona & 0.15 & 4 & 5 & I & 2 \\
\hline Drymophloeus litigiosus (Becc.) H.E.Moore & 0.15 & 1 & 2 & I & 1 \\
\hline Drymophloeus oliviformis (Giseke) Mart. & 0.15 & 3 & 4 & I, P & 2 \\
\hline
\end{tabular}


Table 5. Continuation.

\begin{tabular}{|c|c|c|c|c|c|}
\hline Species per habitat & $\mathbf{R I}$ & $\begin{array}{c}\text { Palm } \\
\text { uses }\end{array}$ & $\begin{array}{c}\text { Palm } \\
\text { use- } \\
\text { reports }\end{array}$ & Countries & References \\
\hline Heterospathe elata Scheff. & 0.15 & 1 & 2 & I & 1 \\
\hline Heterospathe elegans (Becc.) Becc. & 0.15 & 1 & 1 & $\mathrm{P}$ & 1 \\
\hline Heterospathe pulchra H.E.Moore & 0.15 & 3 & 4 & I & 2 \\
\hline Hydriastele biakensis W.J.Baker \& Heatubun & 0.15 & 2 & 5 & I & 2 \\
\hline Hydriastele costata F.M.Bailey & 0.15 & 4 & 6 & I & 3 \\
\hline $\begin{array}{l}\text { Hydriastele cylindrocarpa (Becc.) W.J.Baker \& } \\
\text { Loo }\end{array}$ & 0.19 & 2 & 2 & $\mathrm{P}$ & 1 \\
\hline $\begin{array}{l}\text { Hydriastele dransfieldii (Hambali, Maturb., } \\
\text { Wanggai \& W.J.Baker) W.J.Baker \& Loo }\end{array}$ & 0.15 & 1 & 1 & I & 1 \\
\hline Hydriastele flabellata (Becc.) W.J.Baker \& Loo & 0.19 & 2 & 3 & $\mathrm{I}, \mathrm{P}$ & 1 \\
\hline Hydriastele lurida (Becc.) W.J.Baker \& Loo & 0.15 & 2 & 3 & I & 1 \\
\hline Hydriastele pinangoides (Becc.) W.J.Baker \& Loo & 0.15 & 4 & 4 & I & 2 \\
\hline $\begin{array}{l}\text { Hydriastele wendlandiana (F.Muell.) H.Wendl. \& } \\
\text { Drude }\end{array}$ & 0.15 & 1 & 2 & $\mathrm{P}$ & 1 \\
\hline Korthalsia zippelii Blume & 0.15 & 8 & 11 & $\mathrm{I}, \mathrm{P}$ & 4 \\
\hline $\begin{array}{l}\text { Licuala beccariana (K.Schum. \& Lauterb.) } \\
\text { Furtado }\end{array}$ & 0.19 & 1 & 1 & I & 1 \\
\hline Licuala crassiflora Barfod & 0.15 & 4 & 4 & $\mathrm{P}$ & 1 \\
\hline Licuala urciflora Barfod \& Heatubun & 0.15 & 1 & 1 & I & 1 \\
\hline Linospadix albertisianus (Becc.) Burret & 0.15 & 1 & 1 & $\mathrm{P}$ & 1 \\
\hline Linospadix minor (W.Hill) Burret & 0.15 & 1 & 1 & $\mathrm{P}$ & 1 \\
\hline Livistona muelleri F.M.Bailey & 0.15 & 1 & 1 & $\mathrm{P}$ & 1 \\
\hline $\begin{array}{l}\text { Manjekia maturbongsii (W.J.Baker \& Heatubun) } \\
\text { W.J.Baker \& Heatubun }\end{array}$ & 0.19 & 1 & 1 & I & 1 \\
\hline Metroxylon sagu Rottb. & 0.15 & 31 & 79 & $\mathrm{I}, \mathrm{P}$ & 17 \\
\hline Nypa fruticans Wurmb & 0.15 & 10 & 16 & I & 4 \\
\hline Orania disticha Burret & 0.15 & 1 & 1 & $\mathrm{~N}$ & 1 \\
\hline
\end{tabular}


Table 5. Continuation.

\begin{tabular}{|c|c|c|c|c|c|}
\hline Species per habitat & RI & $\begin{array}{c}\text { Palm } \\
\text { uses }\end{array}$ & $\begin{array}{l}\text { Palm } \\
\text { use- } \\
\text { reports }\end{array}$ & Countries & References \\
\hline Orania lauterbachiana Becc. & 0.15 & 1 & 2 & $\mathrm{P}$ & 2 \\
\hline Orania palindan (Blanco) Merr. & 0.15 & 2 & 2 & I & 1 \\
\hline Orania sylvicola (Griff.) H.E.Moore & 0.15 & 3 & 3 & $\mathrm{~N}$ & 1 \\
\hline Orania zonae A.P.Keim \& J.Dransf. & 0.19 & 1 & 1 & I & 1 \\
\hline Pigafetta filaris (Giseke) Becc. & 0.15 & 10 & 17 & I, P & 7 \\
\hline Pinanga rumphiana (Mart.) J.Dransf. \& Govaerts & 0.15 & 13 & 13 & $\mathrm{I}, \mathrm{P}$ & 3 \\
\hline Ptychococcus lepidotus H.E.Moore & 0.15 & 3 & 4 & $\mathrm{P}$ & 2 \\
\hline Ptychococcus paradoxus (Scheff.) Becc. & 0.15 & 6 & 8 & $\mathrm{I}, \mathrm{P}$ & 3 \\
\hline $\begin{array}{l}\text { Ptychosperma macarthurii (H.Wendl. ex } \\
\text { H.J.Veitch) H.Wendl. ex Hook.f. }\end{array}$ & 0.15 & 1 & 1 & $\mathrm{P}$ & 1 \\
\hline Rhopaloblaste ceramica (Miq.) Burret & 0.15 & 7 & 9 & $\mathrm{I}, \mathrm{P}$ & 3 \\
\hline Rhopaloblaste ledermanniana Becc. & 0.15 & 5 & 10 & $\mathrm{I}, \mathrm{P}$ & 3 \\
\hline Salacca edulis Reinw. & 0.15 & 1 & 1 & I & 1 \\
\hline Saribus rotundifolius (Lam.) Blume & 0.15 & 11 & 12 & $\mathrm{I}, \mathrm{P}$ & 2 \\
\hline $\begin{array}{l}\text { Saribus surru (Dowe \& Barfod) C.D.Bacon \& } \\
\text { W.J.Baker }\end{array}$ & 0.15 & 1 & 1 & $\mathrm{P}$ & 1 \\
\hline $\begin{array}{l}\text { Saribus tothur (Dowe \& Barfod) C.D.Bacon \& } \\
\text { W.J.Baker }\end{array}$ & 0.15 & 5 & 7 & $\mathrm{P}$ & 2 \\
\hline Sommieria leucophylla Becc. & 0.15 & 5 & 5 & I & 2 \\
\hline Wallaceodoxa raja-ampat Heatubun \& W.J.Baker & 0.15 & 2 & 3 & I & 2 \\
\hline \multicolumn{6}{|l|}{ Lower montane forest } \\
\hline Actinorhytis calapparia H.Wendl. \& Drude & 2.00 & 7 & 8 & I & 2 \\
\hline Areca catechu L. & 1.53 & 2 & 2 & $\mathrm{P}$ & 2 \\
\hline Areca macrocalyx Zipp. ex Blume & 1.28 & 6 & 9 & $\mathrm{I}, \mathrm{P}$ & 4 \\
\hline Areca novohibernica (Lauterb.) Becc. & 1.35 & 1 & 1 & $\mathrm{~N}$ & 1 \\
\hline
\end{tabular}


Table 5. Continuation.

\begin{tabular}{|c|c|c|c|c|c|}
\hline Species per habitat & $\mathbf{R I}$ & $\begin{array}{c}\text { Palm } \\
\text { uses }\end{array}$ & $\begin{array}{c}\text { Palm } \\
\text { use- } \\
\text { reports }\end{array}$ & Countries & References \\
\hline Arenga microcarpa Becc. & 0.95 & 11 & 11 & $\mathrm{P}$ & 1 \\
\hline Arenga pinnata (Wurmb) Merr. & 1.11 & 35 & 37 & I & 1 \\
\hline Calamus anomalus Burret & 0.81 & 2 & 2 & $\mathrm{P}$ & 1 \\
\hline Calamus aruensis Becc. & 0.67 & 11 & 15 & $\mathrm{I}, \mathrm{P}$ & 3 \\
\hline Calamus eximius Becc. & 0.63 & 1 & 1 & $\mathrm{P}$ & 1 \\
\hline Calamus longipinna K.Schum. \& Lauterb. & 0.53 & 1 & 1 & I & 1 \\
\hline Calamus oresbius W.J.Baker \& J.Dransf. & 0.58 & 4 & 4 & $\mathrm{P}$ & 1 \\
\hline $\begin{array}{l}\text { Calamus pachypus W.J.Baker, Bayton, J.Dransf. } \\
\text { \& Maturb. }\end{array}$ & 0.58 & 5 & 6 & I & 2 \\
\hline Calamus papuanus Becc. & 0.58 & 1 & 1 & I & 1 \\
\hline Calamus pintaudii W.J.Baker \& J.Dransf. & 0.48 & 3 & 3 & $\mathrm{P}$ & 1 \\
\hline Calamus retroflexus J.Dransf. \& W.J.Baker & 0.48 & 2 & 2 & $\mathrm{P}$ & 1 \\
\hline Calamus vestitus Becc. & 0.48 & 3 & 4 & $\mathrm{P}$ & 1 \\
\hline Calamus vitiensis Warb. ex Becc. & 0.44 & 4 & 4 & I & 1 \\
\hline Calamus zebrinus Becc. & 0.44 & 4 & 5 & I & 1 \\
\hline Calyptrocalyx albertisianus Becc. & 0.44 & 1 & 1 & $\mathrm{P}$ & 1 \\
\hline Calyptrocalyx elegans Becc. & 0.34 & 3 & 3 & $\mathrm{P}$ & 1 \\
\hline Calyptrocalyx lauterbachianus Warb. ex Becc. & 0.34 & 2 & 4 & $\mathrm{P}$ & 2 \\
\hline $\begin{array}{l}\text { Calyptrocalyx merrillianus (Burret) Dowe \& } \\
\text { M.D.Ferrero }\end{array}$ & 0.34 & 2 & 2 & $\mathrm{P}$ & 1 \\
\hline Calyptrocalyx pachystachys Becc. & 0.29 & 1 & 1 & $\mathrm{P}$ & 1 \\
\hline Calyptrocalyx pauciflorus Becc. & 0.29 & 1 & 1 & $\mathrm{P}$ & 1 \\
\hline Calyptrocalyx polyphyllus Becc. & 0.29 & 1 & 1 & $\mathrm{P}$ & 1 \\
\hline Calyptrocalyx yamutumene Dowe \& M.D.Ferrero & 0.29 & 1 & 1 & $\mathrm{P}$ & 1 \\
\hline Caryota no Becc. & 0.29 & 1 & 1 & I & 1 \\
\hline
\end{tabular}


Table 5. Continuation.

\begin{tabular}{|c|c|c|c|c|c|}
\hline Species per habitat & RI & $\begin{array}{c}\text { Palm } \\
\text { uses }\end{array}$ & $\begin{array}{c}\text { Palm } \\
\text { use- } \\
\text { reports }\end{array}$ & Countries & References \\
\hline Caryota rumphiana Mart. & 0.29 & 37 & 53 & $\mathrm{P}$ & 6 \\
\hline Cocos nucifera $\mathrm{L}$. & 0.19 & 17 & 19 & $\mathrm{I}, \mathrm{P}$ & 4 \\
\hline Cyrtostachys loriae Becc. & 0.19 & 1 & 1 & $\mathrm{P}$ & 1 \\
\hline Heterospathe elegans (Becc.) Becc. & 0.19 & 2 & 4 & $\mathrm{P}$ & 3 \\
\hline Hydriastele costata F.M.Bailey & 0.15 & 1 & 1 & I & 1 \\
\hline $\begin{array}{l}\text { Hydriastele cylindrocarpa (Becc.) W.J.Baker \& } \\
\text { Loo }\end{array}$ & 0.15 & 2 & 2 & $\mathrm{P}$ & 1 \\
\hline Hydriastele flabellata (Becc.) W.J.Baker \& Loo & 0.15 & 1 & 1 & $\mathrm{P}$ & 1 \\
\hline Hydriastele gibbsiana (Becc.) W.J.Baker \& Loo & 0.15 & 2 & 2 & I & 1 \\
\hline $\begin{array}{l}\text { Hydriastele ledermanniana (Becc.) W.Baker \& } \\
\text { Loo }\end{array}$ & 0.15 & 2 & 2 & $\mathrm{P}$ & 1 \\
\hline Hydriastele longispatha (Becc.) W.J.Baker \& Loo & 0.15 & 4 & 5 & $P$ & 2 \\
\hline Hydriastele lurida (Becc.) W.J.Baker \& Loo & 0.15 & 1 & 1 & $\mathrm{P}$ & 1 \\
\hline Hydriastele pinangoides (Becc.) W.J.Baker \& Loo & 0.15 & 4 & 6 & $\mathrm{I}, \mathrm{P}$ & 3 \\
\hline $\begin{array}{l}\text { Hydriastele wendlandiana (F.Muell.) H.Wendl. \& } \\
\text { Drude }\end{array}$ & 0.15 & 1 & 1 & $\mathrm{P}$ & 1 \\
\hline Linospadix albertisianus (Becc.) Burret & 0.15 & 1 & 1 & $\mathrm{P}$ & 1 \\
\hline Metroxylon sagu Rottb. & 0.15 & 19 & 47 & $\mathrm{I}, \mathrm{P}$ & 8 \\
\hline Orania lauterbachiana Becc. & 0.15 & 1 & 1 & $P$ & 1 \\
\hline Pigafetta filaris (Giseke) Becc. & 0.15 & 2 & 2 & $\mathrm{P}$ & 1 \\
\hline Pinanga rumphiana (Mart.) J.Dransf. \& Govaerts & 0.15 & 11 & 11 & $\mathrm{P}$ & 1 \\
\hline Ptychococcus lepidotus H.E.Moore & 0.15 & 3 & 5 & $\mathrm{P}$ & 3 \\
\hline Ptychococcus paradoxus (Scheff.) Becc. & 0.15 & 4 & 4 & I & 1 \\
\hline Rhopaloblaste ceramica (Miq.) Burret & 0.15 & 4 & 4 & I & 1 \\
\hline Rhopaloblaste ledermanniana Becc. & 0.15 & 7 & 9 & $\mathrm{I}, \mathrm{P}$ & 2 \\
\hline Salacca edulis Reinw. & 0.15 & 1 & 1 & I & 1 \\
\hline
\end{tabular}


Table 5. Continuation.

\begin{tabular}{|c|c|c|c|c|c|}
\hline Species per habitat & $\mathbf{R I}$ & $\begin{array}{c}\text { Palm } \\
\text { uses }\end{array}$ & $\begin{array}{c}\text { Palm } \\
\text { use- } \\
\text { reports }\end{array}$ & Countries & References \\
\hline $\begin{array}{l}\text { Saribus surru (Dowe \& Barfod) C.D.Bacon \& } \\
\text { W.J.Baker }\end{array}$ & 0.15 & 9 & 11 & $\mathrm{P}$ & 2 \\
\hline Rhopaloblaste ceramica (Miq.) Burret & 0.15 & 4 & 4 & I & 1 \\
\hline Rhopaloblaste ledermanniana Becc. & 0.15 & 7 & 9 & $\mathrm{I}, \mathrm{P}$ & 2 \\
\hline Salacca edulis Reinw. & 0.15 & 1 & 1 & I & 1 \\
\hline $\begin{array}{l}\text { Saribus surru (Dowe \& Barfod) C.D.Bacon \& } \\
\text { W.J.Baker }\end{array}$ & 0.15 & 9 & 11 & $\mathrm{P}$ & 2 \\
\hline \multicolumn{6}{|l|}{ Mid montane forest } \\
\hline Actinorhytis calapparia H.Wendl. \& Drude & 1.38 & 1 & 1 & $\mathrm{P}$ & 1 \\
\hline Areca catechu L. & 0.95 & 1 & 1 & $\mathrm{P}$ & 1 \\
\hline Areca macrocalyx Zipp. ex Blume & 0.96 & 7 & 7 & $\mathrm{P}$ & 3 \\
\hline Arenga microcarpa Becc. & 0.76 & 1 & 1 & $\mathrm{P}$ & 1 \\
\hline Calamus aruensis Becc. & 0.73 & 2 & 2 & $\mathrm{P}$ & 1 \\
\hline Calamus fuscus Becc. & 0.58 & 4 & 4 & $\mathrm{P}$ & 1 \\
\hline Calamus oresbius W.J.Baker \& J.Dransf. & 0.58 & 4 & 4 & $\mathrm{P}$ & 1 \\
\hline Calamus prattianus Becc. & 0.44 & 9 & 10 & I & 2 \\
\hline Calamus vestitus Becc. & 0.34 & 1 & 2 & $\mathrm{P}$ & 1 \\
\hline Calyptrocalyx albertisianus Becc. & 0.29 & 1 & 1 & $\mathrm{P}$ & 1 \\
\hline Calyptrocalyx lauterbachianus Warb. ex Becc. & 0.29 & 1 & 2 & $\mathrm{P}$ & 1 \\
\hline Caryota rumphiana Mart. & 0.29 & 35 & 45 & $\mathrm{P}$ & 4 \\
\hline Cocos nucifera $\mathrm{L}$. & 0.15 & 1 & 2 & $\mathrm{P}$ & 1 \\
\hline Heterospathe elegans (Becc.) Becc. & 0.15 & 3 & 3 & $\mathrm{P}$ & 2 \\
\hline Heterospathe muelleriana (Becc.) Becc. & 0.15 & 3 & 4 & $\mathrm{I}, \mathrm{P}$ & 2 \\
\hline $\begin{array}{l}\text { Hydriastele ledermanniana (Becc.) W.Baker \& } \\
\text { Loo }\end{array}$ & 0.15 & 1 & 1 & $P$ & 1 \\
\hline
\end{tabular}


Table 5. Continuation.

\begin{tabular}{lccccc}
\hline Species per habitat & RI & $\begin{array}{c}\text { Palm } \\
\text { uses }\end{array}$ & $\begin{array}{c}\text { Palm } \\
\text { use- } \\
\text { reports }\end{array}$ & Countries & References \\
\hline Hydriastele longispatha (Becc.) W.J.Baker \& Loo & 0.15 & 4 & 4 & $\mathrm{P}$ & 1 \\
Hydriastele pinangoides (Becc.) W.J.Baker \& Loo & 0.15 & 1 & 1 & $\mathrm{I}$ & 1 \\
Korthalsia zippelii Blume & 0.15 & 2 & 2 & $\mathrm{P}$ & 1 \\
Linospadix albertisianus (Becc.) Burret & 0.15 & 1 & 1 & $\mathrm{P}$ & 1 \\
Metroxylon sagu Rottb. & 0.15 & 12 & 16 & $\mathrm{I}, \mathrm{P}$ & 3 \\
Pinanga rumphiana (Mart.) J.Dransf. \& Govaerts & 0.15 & 11 & 11 & $\mathrm{P}$ & 1 \\
Ptychococcus lepidotus H.E.Moore & 0.15 & 2 & 2 & $\mathrm{P}$ & 2 \\
Upper montane forest & & & & & 1 \\
Metroxylon sagu Rottb. & 0.96 & 12 & 13 & $\mathrm{I}$ & 1 \\
Ptychococcus lepidotus H.E.Moore & 0.15 & 1 & 1 & $\mathrm{P}$ & 1 \\
\hline
\end{tabular}

Lowland tropical rainforest was the best studied habitat and had the greatest number of useful palm species for both countries. This may be explained by the habitat's greater area in New Guinea and its higher palm diversity. By contrast, the absence of reports from upper montane forest and subalpine forest and alpine grasslands reflects the paucity of palms in these habitats, owing to less favourable climatic and edaphic conditions (Dransfield et al., 2000). This resembles patterns in South America, where useful palm diversity decreases with elevation (Macía et al., 2011). Furthermore, very few useful palm species were recorded in New Guinea's lowland savannahs, possibly because of the habitat's restricted extent, coupled with limited publications.

Palm use patterns were relatively similar across habitats and countries, with Utensils and tools, Construction and Human food being the most frequently cited use categories. This indicates that palms are important for subsistence livelihoods in New Guinea. We see a similar pattern in tropical South America where the same use categories are the most frequently cited by indigenous (Macía et al., 2011; Jaimes et al., 2018) and Afro-American communities (Cámara-Leret et al., 2016; Schneider et al., 2017). All palm parts were recorded as having at least one ethnobotanical use, but the stem was the most used palm part. Many villagers still depend on raw materials from their surrounding forests, and our review indicates that palm stems play an important role in house construction, human food (sagu starch) and in the manufacturing of hunting utensils and domestic tools. Further research will be necessary to assess whether harvesting of stems follows sustainable management practices. In New 
Guinea the leaves and fruits were found to be the second and third most utilised palm parts, which resembles the high importance of these plant parts in other tropical areas like north-western South America, where the fruits are the most utilised palm part (Macía et al., 2011).

For medicinal uses, the fruits were the most frequently reported palm part in New Guinea, as is also the case in Madagascar (Gruca et al., 2016), Africa (Gruca et al., 2015) and tropical America (Sosnowska \& Balslev, 2008). In north-western South America, the fruits were the second most frequently utilised palm part for medicinal uses (Paniagua-Zambrana et al., 2015). The stems and roots were the next most frequently used palm parts for medicine in New Guinea. These palm parts are also important in Africa, (Gruca et al., 2015), Madagascar (Gruca et al., 2016), and tropical America (Paniagua-Zambrana et al., 2015; Sosnowska \& Balslev, 2008), suggesting that fruits, stems, and roots have a globally-important role in palm ethno-medicine.

So far, only $5 \%$ of New Guinea's indigenous groups have been cited in the palm ethnobotanical literature and those that have been studied had very few use-reports. Thus, the traditional palm knowledge of New Guinea's inhabitants remains virtually unknown. This figure of 5\% is substantially lower than the $50 \%$ of northwestern South America's indigenous groups that have been reported in palm ethnobotanical studies (Macía et al., 2011). Most areas with previous studies on plant use by New Guinea's indigenous groups will still require additional in-depth ethnobotanical research, because there are practically no monographic studies, and those that exist were based on few informants.

Given the paucity of studies, the most important useful palm species in New Guinea may change when further research is conducted. To date, the most important wild palm species (according to the Relative Importance index) in lowland tropical rainforest, lower montane forest and mid montane forest is Actinorhytis calapparia which is frequently used as a betel nut substitute and for food and cosmetic purposes. Areca macrocalyx was also frequently recorded as a betel nut substitute, indicating the cultural importance of betel nut in New Guinea. Metroxylon sagu was predominately recorded as a staple food in the diet of local indigenous communities, with the consumption of starch from the stems being the most frequently recorded use. Despite Metroxylon sagu being a lowland species, its utilisation in the upper montane forest indicates that indigenous communities of the montane forest will harvest or buy sagu from lower elevations given its nutritional and cultural importance. The most useful palm species in mangrove forest was Nypa fruticans, from which a variety of palm parts are used for food. These species are large palms with wide distributions, suggesting that geographical range size and species' traits may determine their usefulness to local communities, as has been shown in the American tropics (Cámara-Leret et al., 2017).

Our quantitative ethnobotanical review indicates that palms are an important plant family for the indigenous inhabitants of New Guinea. Importantly, our synthesis highlights considerable biological, geographical, and cultural gaps in palm ethnobotanical research. Very few monographic studies on palm uses exist, and we recommend undertaking in-depth ethnobotanical surveys using standard protocols 
(Cámara-Leret et al., 2012) with many more indigenous groups to attain a more complete picture of the multiplicity of palm uses in the region. Our review indicates that indigenous groups in the Asmat, Mamberamo and Waropen Regencies of ING have been the subject of no or limited ethnobotanical studies. Despite being relatively well known for their artistic wooden sculptures, the Asmat had no use-reports in the literature. Similarly, in PNG the East Sepik and Western Provinces had limited palm use documentation, even though ethnobotanical studies have been conducted there (Koch et al., 2015; Skingle, 1970; Ohtsuka et al., 1987). Future research will also be needed on palm ethno-medicine to identify potential taxa which could offer medicinal benefits, including identifying plants with anti-biotic properties which will become increasingly important given increasing anti-biotic resistance (Hossan et al., 2018). For ethno-medicinal studies, detailed accounts of use, preparation, administration and plant parts used should be documented where possible to aid pharmacological evaluation.

DEDICATION AND ACKNOWLEDGEMENTS. We dedicate this paper to Prof. D.J. Mabberley whose innovative Economic Botany course in Leiden and contributions to tropical plant taxonomy have had a profound scientific impact and continue to inspire generations of scholars.

We thank D. Frodin and the staff at the Library, Art and Archives Department of RBG Kew for assistance in finding references and discussions. We extend our gratitude to L. Green (RBG Kew Digital Collections Unit) and S. Arias (Naturalis Biodiversity Center) for assistance with herbarium databases.

\section{References}

Baker, W.J. \& Dransfield, J. (2016). Beyond Genera palmarum: progress and prospects in palm systematics. Bot. J. Linn. Soc. 182(2): 207-233.

Balslev, H., Kahn, F., Millan, B., Svenning, J.C., Kristiansen, T., Borchsenius, F., Pedersen, D. \& Eiserhardt, W.L. (2011). Species diversity and growth forms in tropical American palm communities. Bot. Rev. 77(4): 381-425.

Brummitt, R.K., Pando, F., Hollis, S. \& Brummitt, N.A. (2001). World geographical scheme for recording plant distributions, Ed. 2. Pittsburgh: Hunt Institute for Botanical Documentation, Carnegie Mellon University.

Cámara-Leret, R, Paniagua-Zambrana, N. \& Macía, M.J. (2012). A standard protocol for gathering palm ethnobotanical data and socioeconomic variables across the tropics. In: B.E. Ponman \& R.W. Bussmann (eds) Medicinal plants and the legacy of R.E. Schultes, pp. 41-71. St Louis: Missouri Botanical Garden Press.

Cámara-Leret, R., Paniagua-Zambrana, N., Balslev, H. \& Macía, M.J (2014). Ethnobotanical knowledge is vastly under-documented in northwestern South America. Plos One 9(1): e85794.

Cámara-Leret, R., Copete, J.C., Balslev, H., Gomez, M.S., \& Macía, M. J. (2016). Amerindian and Afro-American perceptions of their traditional knowledge in the Chocó biodiversity hotspot. Econ. Bot. 70(2): 160-175. 
Cámara-Leret, R., Faurby, S., Macía, M.J., Balslev, H., Göldel, B., Svenning, J.C., Kissling, W.D., Rønsted, N. \& Saslis-Lagoudakis, C.H. (2017). Fundamental species traits explain provisioning services of tropical American palms. Nature Plants 3(2): 16220.

Cámara-Leret, R., Schuiteman, A., Utteridge, T., Bramley, G., Deverell, R., Fisher, L.A., McLeod, J., Hannah, L., Roehrdanz, P., Laman, T.G. et al. (2019). The Manokwari Declaration: Challenges ahead in conserving $70 \%$ of Tanah Papua's forests. Forest \& Society 3(1): 148-151.

Cook, F. (1995). Economic botany data collection standard. Royal Botanic Gardens, Kew.

Dransfield, J., Baker, W.J., Heatubun, C.D. \& Witono, J. (2000). The palms of Mt. Jaya. Palms 44(4): 202-208.

Gorenflo, L.J., Romaine, S., Mittermeier, R.A., \& Walker-Painemilla, K. (2012). Co-occurrence of linguistic and biological diversity in biodiversity hotspots and high biodiversity wilderness areas. Proc. Natl. Acad. Sci. U.S.A. 109(21): 8032-8037.

Gruca, M., Blach-Overgaard, A. \& Balslev, H. (2015). African palm ethno-medicine. $J$. Ethnopharmacol. 165: 227-237.

Gruca, M., Blach-Overgaard, A., Dransfield, J. \& Balslev, H. (2016). Medicinal palms (Arecaceae) in Madagascar — undocumented or underutilized? Bot. J. Linn. Soc. 182(2): 517-525.

Haynes, J. \& McLaughlin, J. (2000). Edible palms and their uses. University of Florida. Institute of Food and Agricultural Sciences. Fact Sheet MDCE-00-50-1.

Hide, R. (2014a). A preliminary bibliography of ethnobotanical research in West Papua (Indonesia), Part I: publications 2000-2013. https://www.researchgate.net/project/ Bibliography-of-ethnobotany-of-New-Guinea

Hide, R. (2014b). A preliminary bibliography of ethnobotanical research in West Papua (Indonesia), Part II: publications 1963-1999. https://www.researchgate.net/project/ Bibliography-of-ethnobotany-of-New-Guinea

Hide, R. (2015). Supplement \#1 to 'A preliminary bibliography of ethnobotanical research in West Papua (Indonesia), Part I: publications 2000-2013. https://www.researchgate.net/ project/Bibliography-of-ethnobotany-of-New-Guinea

Hide, R. (2016a). Supplement \#2 to 'A preliminary bibliography of ethnobotanical research in West Papua (Indonesia), Part I: publications 2000-2013. https://www.researchgate.net/ project/Bibliography-of-ethnobotany-of-New-Guinea

Hide, R. (2016b). Supplement \#3 to 'A preliminary bibliography of ethnobotanical research in West Papua (Indonesia), Part I: publications 2000-2013. https://www.researchgate.net/ project/Bibliography-of-ethnobotany-of-New-Guinea

Hide, R. (2017). Supplement \#4 to 'A preliminary bibliography of ethnobotanical research in West Papua (Indonesia), Part I: publications 2000-2013. https://www.researchgate.net/ project/Bibliography-of-ethnobotany-of-New-Guinea

Hossan, M.S., Jindal, H., Maisha, S., Samudi Raju, C., Devi Sekaran, S., Nissapatorn, V., Kaharudin, F., Su Yi, L., Khoo, T.J., Rahmatullah, M. \& Wiart, C. (2018). Antibacterial effects of 18 medicinal plants used by the Khyang tribe in Bangladesh. Pharm. Biol. 56(1): 201-208.

Jaimes-Roncancio, M.S., Betancur, J. \& Cámara-Leret, R. (2018). Useful palms in three indigenous communities of La Pedrera, Colombian Amazonia. Caldasia 40(1): 112128.

Johnson, D.V. (2011). Tropical palms: 2010 revision. Rome: Food and Agriculture Organization of the United Nations.

Kjær, A., Barfod, A.S., Lange, C.B.A. \& Seberg, O. (2004). Investigation of genetic and morphological variation in the sago palm (Metroxylon sagu; Arecaceae) in Papua New Guinea. Ann. Bot. (Oxford) 94(1): 109-117. 
Koch, M., Kehop, D.A., Kinminja, B., Sabak, M., Wavimbukie, G., Barrows, K.M., Matainaho, T.K., Barrows, L.R. \& Rai, P.P. (2015). An ethnobotanical survey of medicinal plants used in the East Sepik province of Papua New Guinea. J. Ethnobiol. Ethnomed. 11: 79.

Macía, M.J., Armesilla, P.J., Cámara-Leret, R., Paniagua-Zambrana, N., Villalba, S., Balslev, H. \& Pardo-de-Santayana, M. (2011). Palm uses in northwestern South America: a quantitative review. Bot. Rev. 77(4): 462-570.

Morcote-Ríos, G. \& Bernal, R. (2001). Remains of palms (Palmae) at archaeological sites in the New World: a review. Bot. Rev. 67(3): 309-350.

Muñoz, G., Trøjelsgaard, K., \& Kissling, W.D. (2019). A synthesis of animal $\square$ mediated seed dispersal of palms reveals distinct biogeographical differences in species interactions. J. Biogeogr. 46(2): 466-484.

Ohtsuka, R., Suzuki, T. \& Morita, M. (1987). Sodium-rich tree ash as a native salt source in lowland Papua. Econ. Bot. 41(1): 55-59.

Paijmans, K. (1976). New Guinea vegetation. Canberrra: CSIRO in association with the Australian National University Press.

Paniagua-Zambrana, N., Cámara-Leret, R. \& Macía, M.J. (2015). Patterns of medicinal use of palms across northwestern South America. Bot. Rev. 81(4): 317-415.

Prance, G.T., Balée, W., Boom, B.M. \& Carneiro, R.L. (1987). Quantitative ethnobotany and the case for conservation in Amazonia. Conserv. Biol. 1(4): 296-310.

Roos, M.C., Keßler, P.J.A., Gradstein, R. \& Baas, P. (2004). Species diversity and endemism of five major Malesian islands: diversity-area relationships. J. Biogeogr. 31: 1893-1908.

Schneider, E., Cámara-Leret, R., Barfod, A. \& Weckerle, C.S. (2017). Palm use by two Chachi communities in Ecuador: a 30-year reappraisal. Econ. Bot. 71(4): 342-360.

Simons, G.F. \& Fennig, C.D. (2018). Ethnologue: languages of the world, 21st edition. http:// www.ethnologue.com. Accessed 27 Apr. 2019

Skingle, D.C. (1970). Some medicinal herbs used by the natives of New Guinea. Mankind 7: $223-225$.

Sosnowska, J. \& Balslev, H. (2008). American palms used for medicine, in the ethnobotanical and pharmacological publications. Rev. Peru. Biol. 15(1): 143-146.

Sosnowska, J. \& Balslev, H. (2009). American palm ethnomedicine: a meta-analysis. J. Ethnobiol. Ethnomed. 5: 43.

ter Steege, H., Pitman, N.C., Sabatier, D., Baraloto, C., Salomão, R.P., Guevara, J.E., Phillips, O.L., Castilho, C.V., Magnusson, W.E., Molino, J.F. and Monteagudo, A. et al. (2013). Hyperdominance in the Amazonian Tree Flora. Science 342(6156): 1243092.

Supplementary Table 1. A. List of references and B. Herbarium specimens consulted.

\section{A. Bibliographic references:}

1. Barfod, A.S. \& Heatubun, C.D. (2009). Two new species of Licuala Thunb. (Arecaceae: Coryphoideae) from North Moluccas and Western New Guinea. Kew Bull. 64(3): 553557.

2. Baker, W.J. \& Dransfield, J. (2002). Calamus longipinna (Arecaceae: Calamoideae) and its relatives in New Guinea. Kew Bull.: 853-866.

3. Baker, W.J. (2002.) Two unusual Calamus species from New Guinea. Kew Bull. 57: 719724.

4. Baker, W.J., Bayton, R.P., Dransfield, J. \& Maturbongs, R.A. (2003). A revision of the Calamus aruensis (Arecaceae) complex in New Guinea and the Pacific. Kew Bull. 58: 351-370. 
5. Baker, W.J. \& Heatubun, C.D. (2012). New palms from Biak and Supiori, Western New Guinea. Palms 56(3): 131-150.

6. Baker, W.J. \& Dransfield, J. (2014). New rattans from New Guinea (Calamus, Arecaceae). Phytotaxa 163(4): 181-215.

7. Banka, R. \& Barfod, A.S. (2004). A spectacular new species of Licuala (Arecaceae, Coryphoideae) from New Guinea. Kew Bull. 59: 73-75.

8. Barfod, A.S. (2000). A new species of Licuala from New Guinea. Palms 44(4): 198-201.

9. Dowe, J.L. \& Ferrero, M.D. (2001). Revision of Calyptrocalyx and the New Guinea species of Linospadix (Linospadicinae: Arecoideae: Arecaceae). Blumea 46(2): 207-251.

10. Dowe, J.L. \& Barfod, A.S. (2001). New species of Livistona R. Br. (Arecaceae) from north Queensland and Papua New Guinea. Austrobaileya: 165-174.

11. Dransfield, J., \& Baker, W.J. (2003). An account of the Papuasian species of Calamus (Arecaceae) with paired fruit. Kew Bull. 58: 371-387.

12. Essig, F.B. (1995). A checklist and analysis of the palms of the Bismarck archipelago. Principes 39(3): 123-129.

13. Keim, A.P. (2012). A monograph of the genus Orania (Arecaceae-Oranieae). Kew Bull. 67: 127-190.

14. Trudgen, M.S. \& Baker, W.J. (2008). A revision of the Heterospathe elegans (Arecaceae) complex in New Guinea. Kew Bull. 63: 639-647.

15. Baker, W.J., Zona, S., Heatubun, C.D., Lewis, C.E., Maturbongs, R.A. \& Norup, M.V. (2006). Dransfieldia (Arecaceae) - a new palm genus from western New Guinea. Syst. Bot. 31(1): 61-69.

16. Heatubun, C.D., Dransfield, J., Flynn, T., Tjitrosoedirdjo, S.S., Mogea, J.P. \& Baker, W.J. (2011). A monograph of the betel nut palms of East Malesia. Bot. J. Linn. Soc. 168: 147-173.

17. Heatubun, C.D., Zona, S. \& Baker, W.J. (2014). Three new genera of arecoid palm from eastern Malesia. Kew Bull. 69: 9525.

18. Heatubun, C.D., Iwanggin, M.P. \& Simbiak, V.I. (2013). A new species of betel nut palm (Areca: Arecaceae) from western New Guinea. Phytotaxa 154(1): 59-64.

19. Powell, J.M. (1976). Ethnobotany. In: K. Paijmans (ed.) New Guinea Vegetation, pp. 106183, Canberra: CSIRO.

20. Cabuy, R.L., Marwa, J., Manusawai, J. \& Rahawarin, Y.Y. (2014). Non-woody plant species of Papuan island forests, a sustainable source of food for the local communities. Indian Journal of Traditional Knowledge 11(4): 586-592.

21. Telban, B. (1988). The role of medical ethnobotany in ethnomedicine: a New Guinea example. J. Ethnobiol. 8(2): 149-169.

22. Sillitoe, P. (1995). An ethnobotanical account of the plant resources of the Wola region, southern Highlands province, Papua New Guinea. J. Ethnobiol. 15(2): 201-235.

23. Heatubun, C.D., Gardiner, L.M. \& Baker, W.J. (2012). Heterospathe elata, a new record for the New Guinea islands. Palms 56(2): 61-64.

24. Baker, W.J. (2005). Rattans and rheophytes of Mubi River. Principes 41(3): 148-157.

25. Essig, F.B. \& Young, B.E. (1980). Palm collecting in Papua New Guinea. I. The Northeast. Principes 24(1): 14-28

26. Anstice, M. (2004). First Contact: A 21 st century discovery of cannibals. UK: Eye Books.

27. Baker, W.J. \& Dransfield, J. (2017). More new rattans from New Guinea and the Solomon Islands (Calamus, Arecaceae). Phytotaxa 305 (2): 061-086.

28. Cook, C.D. \& Webster, J. (2016). Amua-gaig-e: the ethnobotany of the Amungme of Papua, Indonesia. Canadian Science Publishing. 
29. Van der Vossen, H.A.M. \& Umali, B.E. (eds) (2001). Plant resources of South-East Asia No. 14: Vegetable oils and fats. Leiden: Backhuys.

30. Lemmens, R.M.H.J. \& Bunyapraphatsara, N. (eds) (2003). Plant resources of South-East Asia No. 12(3): Medicinal and poisonous plants 3. Leiden: Backhuys.

31. Dransfield, J. \& Manokaran, N. (eds) (1993). Plant resources of South-East Asia No. 6: Rattans. Wageningen: Pudoc.

32. Brink, M. \& Escobin, P. (eds) (2003). Plant resources of South-East Asia No. 17: Fibre plants. Leiden: Backhuys.

33. Westphal, E. \& Jansen, P.C.M. (eds) (1989). Plant resources of South-East Asia: A selection. Wageningen: Pudoc.

34. Percival, M. \& Womersley, J.S. (1975). Floristics and Ecology of the Mangrove Vegetation of Papua New Guinea. Lae: Dept. Forests, Division of Botany.

35. Gagne, W.C. (1982). Staple crops in subsistence agriculture. In: J.L. Gressitt (ed.) Biogeography and Ecology of New Guinea, pp. 229-259. Monographiae Biologicae No The Hague: Junk.

36. Holdsworth, D.K. (1977). Medicinal Plants of Papua New Guinea. South Pacific Commission.

37. Ave, W. (1998). Preliminary list of the use of the plants of Ayawasi. Unpublished report.

38. Woodley, E. (ed.) (1991). Medicinal Plants of Papua New Guinea Part 1: Morobe Province. Wau Ecology Institute Handbook No. 11. Germany: Margraf.

39. World Health Organization (2009). Medicinal Plants in Papua New Guinea. World Health Organization Regional Office for the Western Pacific.

40. Petir A., Materem, D., Yapong, P., Mukarek, S., Okira, M. \& Platts-Mills, T. (1997). Useful Plants of Salemben Village, Madang Province, Papua New Guinea. Madang: Christensen Research Institute.

41. Henty, E.E., (1980). Harmful Plants in Papua New Guinea. Lae: Dept. Forests, Division of Botany.

42. May, R.J. (1984). Kaikai Aniani: A guide to bush foods markets and culinary arts of Papua New Guinea. NSW: Robert Brown \& Associates.

43. Sosef, M.S.M., Hong, L.T. \& Prawirohatmodjo. S. (eds) (1998). Plant Resources of SouthEast Asia No. 5(3): Timber trees: Lesser-known timbers. Wageningen: Backhuys.

44. Brown. (1978). Timbers of the World 8: Australasia. Buckinghamshire: Timber Research and Development Association.

45. van der Vossen, A.M. \& Wessel, M. (eds) (2000). Plant Resources of South-East Asia No. 16: Stimulants. Leiden: Backhuys.

46. Jensen, M. (2001). Trees and Fruits of Southeast Asia: An Illustrated Field Guide (Orchid Guides). Bangkok: Orchid Press

47. Flach, M. \& Rumawas, F. (eds) (1996). Plant Resources of South-East Asia No. 9: Plant Yielding Non-Seed Carbohydrates. Leiden: Backhuys.

48. Burnett, J.B., Davies, M. \& Taylor, G. (2003). Flora and Fauna Survey of the Tangguh LNG Site Papua Province, Indonesia. Bogor: P.T. Hatfindo Prima

49. Arobaya, A.Y.S \& Pattiselanno, F. (2007). Ethnobotany of Dasigo Tribe of Mamberamo in Papua. Beccariana 9(1): 1-4.

50. Haberle, S. (2005). Ethnobotany of the Tari Basin, Southern Highlands Province, Papua New Guinea. Palaeoworks Technical Paper 6

51. Holdsworth, D. \& Damas, K. (1986). Medicinal Plants of Morobe Province, Papua New Guinea Part III: The Finschhafen Coast. Int. J. Crude Drug Res. 24(4): 217-225. 
52. Arobaya \& Pattiselanno. (2011) Human-Plants Interaction: A Case Study on Useful Plants of Dasigo Tribe from Mamberamo, Papua Indonesia. In: Verma, A.K. \& Singh G.D. (eds) Perspectives in Animal Ecology and Reproduction, pp. 225-232, New Delhi: Daya Publishing House.

53. Jorim, R.Y., Korape, S., Legu, W., Koch, M., Barrows, L.R., Matainaho, T.K. \& Rai, P.P (2012). An ethnobotanical survey of medicinal plants used in the eastern highlands of Papua New Guinea. Journal of Ethnobiology and Ethnomedicine, 8:47.

54. Lense, O. (2012). The wild plants used as traditional medicines by indigenous people of Manokwari, West Papua. Biodiversitas 13(2): 98-106.

55. Milliken, W. (1994). Ethnobotany of the Yali of West Papua. Edinburgh: Royal Botanic Garden

56. Prescott, T.A.K., Kiapranis R. \& Maciver, S.K. (2012). Comparative ethnobotany and inthe-field antibacterial testing of medicinal plants used by the Bulu and inland Kaulong of Papua New Guinea. J. Ethnopharmacol. 139(2): 497-503.

57. Nombo, P. \& Leach, J. (2010). Reite plants: an ethnobotanical study in Tok Pisin and English. Canberra: ANU E Press

58. Ohtsuka, R (1994). Subsistence ecology and carrying capacity in two Papua New Guinea Populations. J. Biosoc. Sci. 26: 395-407.

59. Rahawarin, Y.Y. (2017). Non-timber products extracted activities of the upstream Mamberamo basin's traditional communities of West Papua, Indonesia. Asian J. Forestry 1(1): 23-26.

60. Thomas, B. (2003). The Psychoactive Flora of Papua New Guinea. J. Psychoactive Drugs 35(2): 285-293.

61. Wiriadinata, H. (1995). Ethnobotany of Economic Plants in the Baliem Valley, Jayawijaya, Irian Jaya.

62. Yoshinaga, J., Suzuki, T., Ohtsuka, R., Kawabe, T., Hongo, T., Imai, H., Inaoka, T. \& Akimichi, T. (1991). Dietary selenium intake of the Gidra, Papua New Guinea. Ecol. Food Nutr. 26(1): 27-36.

63. Thaman, R.R. (1992). Batiri Kei Baravi: The Ethnobotany of Pacific Island Coastal Plants. Atoll Res. Bull., 361.

64. Barrau, J. (1959). The Sago Palms and Other Food Plants of Marsh Dwellers in the South Pacific Islands. Econ. Bot. 13(2): 151-162.

65. Richards, S.J. \& Suryadi, S. (2002). Biodiversity Assessment of Yongsu-Cyclops Mountains and the Southern Mamberamo Basin, Papua, Indonesia. RAP Bulletin of Biological Assessment, 25, 986-990.

66. Boissière, M., Liswanti, N., Padmanaba, M. \& Sheil, D. (2007). People priorities and perceptions: Towards conservation partnership in Mamberamo. Jakarta, Indoneisa: Center for International Forestry Research.

67. Tsuji, K., Ghazalli, M.N.F., Ariffin, Z., Nordin, M.S., Khaidizar, M.I., Dulloo, M.E. \& Sebastian, L.S. (2011). Biological and Ethnobotanical Characteristics of Nipa Palm (Nypa fructicans Wurmb): A Review. Sains Malaysiana 40(12): 1407-1412.

68. Kameubun, K.M.B. (2014). Indigenous knowledge, morphological variation and genetic diversity of Kava (Piper methysticum Forst.) in Merauke, Papua, Indonesia. Ph.D. thesis. Georg-August-Universitat Goettingen, Germany.

69. Marwa, J., Cabuy, R.L. \& Tawer, A.Y. (2013). Potential and pattern of utilization of Renewable Energy sources from vegetation based on local knowledge of Ireres tribe in Tambrauw, West Papua, Indonesia. Indian Journal of Traditional Knowledge 12(2): 411-417. 
70. Muller, K. (2006). The Biodiversity in New Guinea. Manokwari: Universitas Negeri Papua

71. Pouwer, J. (2010). Gender, ritual and social formation in West Papua: A configurational analysis comparing Kamoro and Asmat. Leiden: KITLV Press.

72. Andersen, Ø.L. (2006). The Ketengban people of the greater Nongme area and their environment. Jayapura: Cenderawasih University.

73. Andersen, Ø.L. (2007). The Lepki people of Sogber River, New Guinea. Jayapura: Cenderawasih University.

74. Andersen, Ø.L. (2006). Babrongko: Material culture of a Lake Sentani Village, New Guinea. Jayapura: Cenderawasih University.

75. Pattiselanno, F. (2008). Man-Wildlife interaction: Understanding the concept of conservation ethics in Papua. Tiger Paper 35(4): 10-12.

76. Godschalk, J.A. (1993). Sela Valley: An Ethnography of a Mek Society in the Eastern Highlands, Irian Kaya, Indonesia. Thesis. Vrije Universiteit.

77. Prima, H. (2002). Studi Etnobotani Tumbuhan Obat Masyarakat Kamoro Di Dataran Rendah Pt Freeport Indonesia, Kabupaten Mimika, Papua.

78. Purwanto, Y. (2003). Studi etnoekologi masyarakat Dani-Baliem Dan Perubahan Lingkungan Dilemb Ah Baliem, Jayawijaya, Irian Jaya. Berita Biologi 6(5): 661-678.

79. Arobaya, A.Y.S. \& Pattiselanno, F. (2010). Hutan mangrove dan kelompok etnis di Papua: Bentuk pemanfaatannya oleh masyarakat lokal. Biota 15(3).

80. Sembori, F. (2009). Inventarisasi Jenis Tumbuhan Pangan Lokal pada Masyarakat Ambaidiru Distrik Kosiwo, Kabupaten Yapen Waropen. Jurnal Biologi Papua 1(1): 36-41.

81. Rawaharin, Y.Y. (2005). Inventory of palm species in Mioswaar island, Teluk Wondama Regency, West Irian Jaya (Papua). Biodiversitas 6(2): 108-112,

82. Sada, J.T. \& Tanjung, D.R.H.R. (2010). Keragaman Tumbuhan Obat Tradisional di Kampung Nansfori Distrik Supiori Utara, Kabupaten Supiori-Papua. Jurnal Biologi Papua 2(2): 39-46.

83. Susiarti, S. (2003). Use of plants in Muy Use of Plants in Muyu Community at Soa Village and Its Surroundings, Merauke, Papua. Benta Biologi 6(5): 705-711.

84. Arobaya, A.Y.S \& Pattiselanno, F. (2007). The Useful Plants of Dani Ethnic Groups at The Baliem Valley of Papua. Biota 12(3): 192-195.

85. Sarimole, E. (2014). Pemanfaatan Tumbuhan Hutan Sebagi Obat Tradisional Masyarakat Di Kampung Yenbekwan, Distrik Mansuar, Kabupaten Raja Ampat. Prosiding Seminar Nasional Raja Ampat Waisai 12-13 AGUSTUS 2014

86. Maturbongs, R.A., Arobaya, A.Y.S., Heatubun, C.D. \& Pugu, Y.R. (2000). Etnobotani suku Tepin di pulau Salawati kabupaten dati Sorong, Irian Jaya. Beccariana 2(2): 38-43

87. Rumbiak, F. \& Heatubun, C.D. (2001). Pemanfaatan palem oleh masyarakat etnik Wondama di Tandia Kecamatan Wasior-Manokwari. Beccariana 3(2): 31-37

88. Desianto. (2002). Diversitas palem pada bagian utara kawasan cagar alam pegunungan Cyclops.

89. Hastuti, S.D., Tokede, M.J. \& Maturbongs, R.A. (2002). Tumbuhan Obat Menurut Etnobotani suku Biak. Beccariana 4(1): 20-40.

90. Indaryani, W., Wanggai, F. \& Maturbongs, R.A. (2002). The utilization of traditional medicine plants by Wondama tribe in Manokwary regency. Beccariana 4(1): 56-67.

91. Morren \& Frodin, D.G. (1992). A preliminary vernacular guide to the vegetation of northern Telefomin district, Papua New Guinea. Department of Human Ecology Research Paper/New Jersey Agricultural Experiment Station Publication P-26501-1-92. New Brunswick, N.J., Rutgers, The State University of New Jersey 
92. Purwanto, Y. (2002). Gestion De La Biodiversite: Relations Aux Plantes Et Dynamiques Vegetales Chez Les Dani De La Vallee De La Baliem En Irian Jaya, Indonesie. Reinwardtia 12(1): 1-94.

93. Dahruddin, H., Farida, W.R. \& Rhoman, A.E. (2005). Jenis-Jenis Tumbuhan Sumber Pakan dan Tempat Bersarang Kuskus (Famili Phalangeridae) di Cagar Alam Biak Utara, Papua. Biodiversitas 6(4): 253-258

94. Handayani, N.H.D. (2014). Etnofarmakologi Papua. Unpublished report.

95. Haryanto, D., Tanjung, R.H.R. \& Kameubun, K.M.B. (2009). Pemanfaatan Tumbuhan Obat Masyarakat Marind yang Bermukim di Taman Nasional Wasur, Merauke. Jurnal Biologi Papua 1(2): 58-64.

96. Hiepko, P. \& Schultze-Motel, W. (1981). Floristische und ethnobotanische Untersuchungen im Eipomek-Tal, Irian Jaya (West-Neuguinea), Indonesien. Mensch, Kultur und Umwelt im zentralen Bergland von West-Neuguinea 7.

97. Nurapriyanto, I., Tuharea, A. \& Arifin, N. (2005). Sistem Pengusahaan Beberapa Hasil Hutan Bukan Kayu Dan Alur Tataniaganya Di Jayapura, Papua. Penelitian Sosial Ekonomi dan Kebijaken Kehutanan. Jayapura.

98. Kanro, M.Z., Rouw, A., Widjono, A. \& Syasuddin, A. (2003). Tanaman Sagu Dan Pemanfaatannya Di Propinsi Papua. Jurnal Penelitian dan Pengembangan Pertanian 22(3): 116-124.

99. Mahmud, M. (2011). Vegetasi Mangrove sebagai Bahan Makanan pada Empat Suku di Papua (Mangrove Vegetation as Foods amongst Ethnics in Papua). Biota 16(1): 88-94.

100. Uji, T. (2007). Review: Keanekaragaman Jenis Buah-Buahan Asli Indonesia dan Potensinya (Species diversity of indigenous fruits in Indonesia and its potenial). Biodiversitas 8(2): 157-167.

101. Yansip, S.M., Tambaru, E. \& Salam, M.A. (2017). Jenis-Jenis Tumbuhan Berkhasiat Obat Tradisional Di Masyarakat Desa Yanim Dan Braso Distrik Kemtuk Gresi Kabupaten Jayapura (The Kind Of Plants To Use As Traditional Medicine For People Who Live At Village Of Yanim And Braso, District Of Kemtuk Gresi Of Jayapura Regency). Jurnal Biologi Makassar 2(2): 1-11.

102. Yewen, M., Mudjirahayu, Pattiasina, T.F. \& Bawole, R. (2008). Struktur Komunitas Dan Penyebaran Mangrove Serta Upaya Pengelolaannya Oleh Masyarakat Distrik Teminabuan, Kabupaten Sorong Selatan. Dalam Prosiding Konferensi Nasional VI Pengelolaan Sumberdaya Pesisir dan Lautan tanggal 26-29 Agustus 2008 di Manado, 305-319.

103. Leonard, D., Wanggai, J. \& Manusawai, J. (2003). Pemanfaatan Tumbuhan Dalam Ekosistem Mangrove Oleh Masyarakat Di Kampung Senebuay Distrik Rumberpon Kabupaten Manokwari (The use of Plants from Mangrove Forest by Local People in Senebuay Village District of Rumberpon Manokwari). Beccariana 5(2): 97-108.

104. La Hisa, Mahuze, A. \& Arka, I.W. (2016). Etnobotani Masyarakat Suku Marori di Kabupaten Merauke, Papua. Wasur National Park Hall.

105. Attamimi, F. (1997). Pengetahuan masyarakat suku mooi tentang pemanfaatan sumber daya nabati di dusun maibo desa aimas kabupaten sorong. Thesis. Cenderwasih University.

106. Djamalui, V.P. (1998). Jenis-jenis tumbuhan berkayu dan pemanfaatannya dalam kehidupan suku Sougb di desa sururey kecamatan Sururey kabupaten Dati ii Manokwari. Thesis. Cenderwasih University.

107. Gusbager, P., Sinaga, N.I. \& Heatubun, C.D. (2003). Jenis Palem Di Daerah Aliran Sungai Tami Arso-Jayapura (Palem Species in the River Basin od Tami, Arso Jayapura). Beccariana 5(2): 82-96. 
108. Duwila, R., Sinaga, N.I. \& Rahawarin, Y.Y. (2003). Pemanfaatan jenis-jenis Kayu Sebagai Bahan Baku Pembuatan Perahu Tradisional oleh Masyarakat Kampung Wariap Distrik Ransiki Kabupaten Manokwari (The use of three species for traditional boats by local people in Wariap Village District of Ransiki, Manokwari). Beccariana 5(2): 109-116.

109. Hamzah, P., Kesaulija, E.M. \& Rahawarin, Y. (2003). Pemanfaatan Tumbuhan Obat Tradisional Oleh Masyarakat Pulau Mansinam Kabupaten Manokwari (The Use of Plants for Traditional Medicine by People Living in Mansinam Island of Manokwari). Beccariana 5(2): 52-60.

110. Howay, M., Sinaga, N.I. \& Kesaulija, E.M. (2003). Pemanfaatan tumbuhan Sebagai Obat Tradisional Oleh Masyarakat Suku Maibrat Di Kampung Sembaro Distrik Ayamaru Kabupaten Sorong (Utilisation of Plants as Traditional Medicines by Maibrat Tribe in Sorong). Beccariana 5(1): 24-34.

111. Nega, L.B., Wasaraka, N.A.R. \& Heatubun, C.D. (2003). Eksplorasi Jenis Palem Pada Kawasan Hutan Dataran Rendah Bayeda Distrik Teluk Arguni (Exploration of Species in the Lowland Forest of Bayeda Distract Teluk Arguni). Beccariana 5(2): 67-81.

112. SP3T (2016). Tumbuhan Obat Tradisional Papua Berdasarkan Kearifan Lokal Masyarakat. Dinas Kesehatan Provinsi Papua Sentra Pengembangan Dan Penerapan Pengobatan Tradisional (Sp3t).

113. Inama. (2008). Kajian etnobotani masyarakat suku marind sendawi anim di kawasan taman nasional wasur, kabupaten merauke, propinsi papua. Institut Pertanian Bogor.

114. Aji, C.A. (2000). Pengetahuan lokal Pembuatan Perahu Tradisional Oleh Suku Biak Di Kecamatan Warsa Kabupaten Biak Numfor. Thesis. Universitas Cenderwasih.

115. Triestini, Y. (2000). Pemanfaatan jenis kayu oleh masyarakat ambai sebagai bahan baku komponen bangunan rumah berlabuh. Thesis. Universitas Cenderwasih.

116. Pamassangan, J. (2012). Pentingnya lanskap hutan dan keragaman tumbuhan menurut persepsi masyarakat adat ibele kabupaten jayawijaya. Thesis. Universitas Negeri Papua.

117. Remetwa, R.P.R. (2012). Kearifan masyarakat lokal kampung rotea dalam pemanfaatan hasil hutan bukan kayu (HHBK) Nabati sebagai bahan makanan dan obat-obatan di distrik bonggo kabupaten sarmi. Thesis. Universitas Negeri Papua.

118. Saragih, E., Sadsoeitoboen, M.J. \& Pattiselanno, F. (2010). The diet of spotted cuscus (Spilocuscus maculatus) in natural and captivity habitat. Nusantara Bioscience 2(2): 78-83.

119. Sheil, D., van Heist. M., Boissiere, M., Liswanti, N., Basuki, I. \& Wan, M. (2004). Building capacity for Multidisciplinary Landscape Assessment in Papua: three phases of training and pilot assessments in the Mamberamo Basin. Center for International Forestry Research, Conservation International (Papua Program), Lembaga Ilmu Pengetahuan Indonesia (LIPI)

120. Zona, S. (2005). A Revision of Ptychococcus (Arecaceae). Syst. Bot. 30(3): 520-529.

121. Sinery. A.S., Boer, C. \& Farida, W.R. (2013). Population dynamics of cuscus in tourist island of Ahe, District of Nabire, Papua. Biodiversitas 14(2): 95-100.

122. Sinery, A.S. (2006). Jenis Kuskus di Taman Wisata Gunung Meja Kabupaten Manokwari, Irian Jaya Barat. Biodiversitas 7(2): 175-180.

123. Susiarti, S. (2005). Jenis-Jenis Pengganti Pinang dan Gambir dalam Budaya Menginang Masyarakat di Kawasan Taman Nasional Wasur, Merauke, Papua. Biodiversitas 6(3): 217-219.

124. Triantoro, R.G.N., Lekitoo, K., Rumawak, Z.L. \& Rumawak, M. (2008). Keanekaragaman Jenis Flora Pada Cagar Alam Pegunungan Yapen Tengah, Provinsi Papua (Biodiversity of Flora in Central Yapen Mountain Range Nature Reserve, Papua Province). Info Hutan 5(1): 25-34. 
125. Uji, T. (2005). Keanekaragaman Dan Potensi Flora Di Cagar Alam Pegunungan Cyclops, Papua. Jurnal Teknologi Lingkungan 6(3): 485-495.

126. Wahyudi, W. (2017). Non-Timber Forest Product (NTFP) Commodities Harvested and Marketed by Local People at the Local Markets in Manokwari-West Papua. Indonesian J. Forestry Res. 4(1): 27-35.

127. Van Heist, M., Liswanti, N., Boissière, M., Padmanaba, M., Basuki, I. \& Sheil, D. (2015). Exploring Local Perspectives for Conservation Planning: A Case Study from a Remote Forest Community in Indonesian Papua. Forests 6: 3278-3303.

128. Sirami, E.V. (2010). Pohon Buah Hitam (Haplolobus spp.) Apa Keistimewaannya bagi Masyarakat Pesisir Teluk Wondama. Warta Konservasi Latan Basah, 18(2): 20-21.

129. Blench, R. (2008). A history of fruits on the Southeast Asian mainland. Occasional Paper 4: 115-137.

130. Fatem, S., Peday, M.H. \& Yowei, R.N. (2014). Ethno-Biological Notes on the Meyah Tribe from the Northern Part of Manokwari, West Papua (Catatan Etnobiologi Pada Suku Meyah di Pantai Utara Manokwari, Papua Barat). Jurnal Manusia dan Lingkungan 21(1): 121-127.

131. Noor, Y.R., Khazah, M. \& Suryadiputta (2012). Panduan Pengenalan Mangrove di Indonesia. 3rd edition.

132. Woretma, M. (2013). Keanekaragaman Tumbuhan Pangan dan Obat pada Masyarakat Suku Mbaham Mata di Kampung Werabuan, Kabupaten Fakfak (Food and Medicinal Plant Diversity, in Mbaham Mata Tribe Society in Werabuan Village, Fakfak District). Thesis, Institut Pertanian Bogor.

133. Saragih. 2008. Kohabitasi Antara Walabi Lincah (Macropus agilis papuanus Peters and Doria, 1875) Dan Rusa Timor (Cervus timorensis de Blainville, 1822) Di Savana Campuran Udiudi Sptn Iii Taman Nasional Wasur, Papua. Thesis, Institut Pertanian Bogor.

134. Ungirwalu, A., Awang, S.A., Maryudi, A. \& Suryanto, P. (2016). Pengelolaan Adaptif Pemanfaatan Buah Hitam (Haplolobus monticola Blumea) Etnis Wandamen-Papua (Adaptive Management Utilization of Black Fruit (Haplolobus monticola Blumea) Ethnic Wandamen-Papua). Jurnal Manusia dan Lingkungan 23(2): 266-275.

135. Heatubun, C.D. (2016). Areca jokowi: A New Species of Betel Nut Palm (Arecaceae) from Western New Guinea. Phytotaxa 288(2): 175-180.

136. Mangera, Y. (2011). Analisis Vegetasi Jenis Pohon Di Kawasan Hutan Kampung Wasur Pada Taman Nasional Wasur Distrik Merauke Kabupaten Merauke. Agricola 1(1): 1835.

137. Laufa, T.M. (2009). Sago research in Pacific Island Countries and Southeast Asia - A Review. South Pacific Studies 29(2): 29-47.

138. Heatubun, C.D., Lekitoo, K. \& Matani, O.P. (2014). Palms on the Nickel Island: An Expedition to Gag Island, Western New Guinea. Palms 58(3): 115-134.

139. Kogoya, B., Guritno, B. \& Arifin, S.A. (2014). Bioactive Components of Pandan's Fruits from Jayawijaya Mountains, Papua, Indonesia. Journal of Environmental Science, Toxicology and Food Technology 8(8): 1-8.

140. Nugroho, W., Cargill, C.F., Putra, I.M., Kirkwood, R.N. Trott, D.J., Salasia, S.I.O. \& Reichel, M.P. (2015). Traditional Pig farming practices and productivity in the Jayawijaya region, Papua province, Indonesia. Trop. Anim. Health Prod. 7(3): 495-502.

141. Pangau-Adam, M. \& Mühlenberg, M. (2014). Palm Species in the Diet of the Northern Cassowary (Casuarius unappendiculatus) in Jayapura Region, Papua, Indonesia. Palms 58(1): 19-26. 
142. Heatubun, C.D. (2000). Beberapa Jenis Palem Hias Di Kawasan Hutan Teminabuan Sorong, Irian Jaya (Some Species of Ornamental Palm in Teminabuan Forest Area, Sorong, Irian Jaya). Beccariana 2(2): 70-74.

143. Linthin, N. (2000). Identifikasi jenis-jenis vegetasi sebagai pakan kuskus di pulau moor kecamatan napan weinami kabupaten nabire. Thesis. Universitas Cenderawasi.

144. Krey, D.L.Y. (1998). Teknik Pembibitan Dan Penanaman Sagu (Metroxylon spp.) Secara Tradisional Oleh Penduduk Asli Sentani Di Kabupaten Dati Ii Jayapura. Thesis. Universitas Cenderawasi.

145. Hartzlet, M. (1987). Health Care Options and Attitudes Amoung the Sentani. Irian 15: 49-60.

146. Collier, K.J. (1987). Illness and Traditional Medicines of the Tepera. Irian 15: 62-103.

147. Thomas, B. (2000). Psychoactive Plant Use in Papua New Guinea: A Reivew. Sci. New Guinea 25(1,2,3): 33-59.

148. Wiriadinata, H. et al. (1992). Plants and Flowers of Baliem Valley Jayawijaya. Bogor: Research and Development Centre For Biology, Indonesian Institue of Sciences

149. Holdsworth, D. \& Wamoi, B. (1982). Medicinal Plants of the Admiralty Islands, Papua New Guinea Part I. Int. J. Crude Drug Res. 20(4): 169-181.

150. Holdsworth, D. (1993). Medicinal Plants of the Oro (Northern) Province of Papua New Guinea. Int. J. Pharmacog. 31(1): 23-28.

151. Holdsworth, D. \& Lacanienta, E. (1981). Traditional Medicinal Plants of the Central Province of Papua New Guinea Part II. Q. J. Crude Drug Res. 19(4): 155-167.

152. Holdsworth, D. (1991). Medicinal Plants of the Central Province of Papua New Guinea: Part V. Coastal Villages to the West and East of Port Morseby. Int. J. Pharmacog. 29(3): 231-236.

153. Holdsworth, D. (1992). Medicinal Plants of the Gazelle Peninsula, New Britain Island, Papua New Guinea. Part I. Int. J. Pharmacog. 30(3): 185-190.

154. Holdsworth, D. (1993). Medicinal Plants of the Gazelle Peninsula, New Britain Island, Papua New Guinea. Part II*. Int. J. Pharmacog. 31(1): 19-22.

155. Holdsworth, D., Gideon, O. \& Pilokos, B. (1989). Traditional Medicinal Plants of New Ireland, Papua New Guinea. Part III. Konos, Central New Ireland. Int. J. Crude Drug Res. 27(1): 55-61.

156. Batet, K., Koil, U. \& Hertel, H. (1998). Traditional Plant Use by the Didipa Clan, Baitabang, Papua New Guinea. Madang: Kristen Press.

157. Case, R.J., Pauli, G.F. \& Soejarto, D.D. (2005). Factors in Maintaining Indigenous Knowledge among the Ethnic Communities of Manus Island. Econ. Bot. 59(4): 356365.

158. Sam, K., Legi, S. \& Lepš, J. (2005). Ethnobotany of Penis Sheaths (Phallocrypts) in Papua New Guinea. Bot. Electr. News 490.

159. Gardner, R.O. (2010). Plant names of the Kalam (Upper Kaironk Valley, Schrader Range, Papua New Guinea). Records of the Auckland Museum 47: 5-50.

160. Hill, R. (2001). Traditional paint from Papua New Guinea: Context, materials and techniques, and their implications for conservation. The Conservator 25(1): 49-61.

161. Ogo, T., Inomata, N. \& Yamamoto, Y. (1987). Plant Species Used in Papua New Guinea and Solomon Islands. Jap. J. Trop. Agric. 31(1): 16-27.

162. Ohtsuka, R., Suzuki, T. \& Morita, M. (1987). Sodium-Rich Tree Ash as a Native Salt Source in Lowland Papua. Econ. Bot. 41(1): 55-59.

163. Bourke, R.M. (2001). Intensification of agricultural systems in Papua New Guinea. Asia Pacific Viewpoint 42(2/3): 219-235. 
164. Bourke, R.M. (1996). Edible Indigenous Nuts in Papua New Guinea. in: Stevens, M. L., Bourke, R. M. and Evans, B. R. (ed.) South Pacific Indigenous Nuts, pp. 45-55, Canberra: ACIAR. Proceedings of a workshop held from 31 October to 4 November 1994 at Le Lagon Resort, Port Vila, Vanuatu. ACIAR Proceedings No. 69, 176 pp.

165. Skingle, D.C. (1970). Some Medicinal Herbs Used by the Natives of New Guinea. Mankind 7(3): 223-225.

166. Hide, R., Kimin, M., Kora, A., Kua, G. \& Kua. K. (1979). A Checklist of Some Plants in the Territory of the Sinasina Nimai (Simbu Province, Papua New Guinea), with Notes on Their Uses. Department of Anthropology, University of Auckland.

167. Flavelle, A.J. (1991). A Traditional Agroforestry Landscape on Fergusson Island, Papua New Guinea. PhD thesis. University of British Columbia, Canada.

168. Hide, R.L. (1984). The Research Report of the Simbu Land Use Project Volume VI: South Simbu: Studies in Demography, Nutrition and Subsistence. Boroko, Papua New Guinea: The Institute of Applied Social and Economic Research.

169. Koch, M. Kehop, D.A., Kinminja, B., Sabak, M., Wavimbukie, G., Barrows, K.M., Matainaho, T.K., Barrows, L.R. \& Rai, P.P. (2015). An ethnobotanical survey of medicinal plants used in the East Sepik province of Papua New Guinea. $J$. Ethnobiol. Ethnomed. 11: 79.

170. Takeuchi, W. (2000). A Floristic and Ethnobotanical Account of the Josephstaal Forest Management Agreement Area, Papua New Guinea. Sida 19(1): 1-63.

171. Bourke, R.M. (2010). Altitudinal limits of 230 economic crop species in Papua New Guinea. In: Haberle, S., Stevenson, J. \& Prebble, M. (eds) Altered Ecologies: Fire, Climate and Human Influence on Terrestrial Landscapes, pp. 473-512, Canberra: ANU E Press.

172. Bourke, R.M. (1992). Fifty years of Agricultural Change in A New Guinea Highland Village. In: Levett M.P., Earland, J. \& Heywood, P. Changes in Food and Nutrition in Papua New Guinea. Proceedings of the First Papua New Guinea Food and Nutrition Conference: Changes in Food and Nutrition in the Last Three Decades, pp. 26-53, Port Moresby: University of Papua New Guinea Press and Department of Agriculture and Livestock

173. Dwyer, P.D. \& Minnegal, M. (1990). Yams and Megapode Mounds in the Lowland Rain Forest of Papua New Guinea. Hum. Ecol. 18(2): 177-185.

174. Dwyer, P.D. \& Minnegal, M. (1992). Ecology and Community Dynamics of Kubo People in the Tropical Lowlands of Papua New Guinea. Hum. Ecol. 20(1): 21-55.

175. Dwyer, P.D. \& Minnegal, M. (1994). Sago Palms and Variable Garden Yields: A Case Study from Papua New Guinea. Man and Culture in Oceania 10: 81-102.

176. French, B.R. (2006). Sago and Gardening Foi Kutubu: A subsistence food production system based on sago production. Tasmania: Food Plants International.

177. Barfod, A.S., Banka, R. \& Dowe, J.L. (2001). Field Guide to Palms in Papua New Guinea with a multi-access key and notes on the genera. Townsville: AAU Reports, 40.

178. Petoe, P., Cámara-Leret, R. \& Baker, W.J. (2018). A monograph of the Hydriastele wendlandiana group (Arecaceae: Hydriastele). Kew Bull. 73(1): 17.

179. Heatubun, C.D., Petoe, P. \& Baker, W.J. (2018). A monograph of the Nengella group of Hydriatele (Arecaceae). Kew Bull. 73(1): 18

180. Macap, H. (2013). Etnobotani Pangan Suku Matbat Di Pulau Misool Kabupaten Raja Ampat Papua Barat. Thesis. Institut Pertanian Bogor, Indonesia.

181. French, B.R. (1986). Food plants of Papua New Guinea: a compendium, $2^{\text {nd }}$ ed. Tasmania: Australia Pacific Science Foundation. 
182. Rappaport, R.A. (1968). Pigs for the Ancestors: Ritual in the ecology of a New Guinea people. Yale University Press.

183. Miklouho-Maklai, N.N. \& Mueller, F.B. (1885). List of plants in use by the natives of the Maclay-coast, New Guinea. Proc. Linn. Soc. New South Wales 10: 346-358.

184. Oomen, H. (1971). Ecology of Human Nutrition in New Guinea: evaluation of subsistence patterns. Ecol. Food Nutr. 1: 1-16.

185. Coiffier, C. (2002). Une « huile » végétale aux multiples usages dans la région du fleuve Sépik (Papouasie Nouvelle-Guinée). J. Soc. Ocean. 114-115.

186. Juillerat. (1984). D'Acorus à Zingiber: taxinomie et usages des plantes cultivées chez les Yafar de Nouvelle-Guinée. J. Agric. Tradit. Bot. Appl. 1-2: 3-31

187. Kocher-Schmid, C. (1991). Of People and Plants: A Botanical Ethnography of Nokopo Village, Madang and Morobe Provinces, Papua New Guinea. Ethnologisches Seminar der Universität und Museum für Völkerkunde Basel. 
B. Herbarium specimens (Collector name and collection number):

1. Baker, W.J. 410

2. Baker, W.J. 421

3. Baker, W.J. 431

4. Baker, W.J. 432

5. Baker, W.J._436

6. Baker, W.J._566

7. Baker, W.J._567

8. Baker, W.J._569

9. Baker, W.J. 570

10. Baker, W.J._572

11. Baker, W.J. 573

12. Baker, W.J. 574

13. Baker, W.J._579

14. Baker, W.J._582

15. Baker, W.J._591

16. Baker, W.J. 611

17. Baker, W.J._612

18. Baker, W.J._613

19. Baker, W.J.622

20. Baker, W.J._627

21. Baker, W.J. 631

22. Baker, W.J.632

23. Baker, W.J. 633

24. Baker, W.J. 634

25. Baker, W.J. 643

26. Baker, W.J._646

27. Baker, W.J._647

28. Baker, W.J._970

29. Baker, W.J._1042

30. Baker, W.J._1043

31. Baker, W.J._1044

32. Baker, W.J._1045

33. Baker, W.J._1049

34. Baker, W.J. 1062

35. Baker, W.J._1063

36. Baker, W.J. 1064

37. Baker, W.J._1068

38. Baker, W.J._1099

39. Baker, W.J._1102

40. Baker, W.J._1128

41. Baker, W.J._1334

42. Baker, W.J._1368

43. Baker, W.J._1374

44. Baker, W.J._1379

45. Baker, W.J._1389

46. Banka, R._2000

47. Banka, R._2001

48. Banka, R._2002

49. Banka, R. 2004

50. Banka, R._2005
51. Banka, R._2006

52. Banka, R._2009

53. Barfod, A.S. 390

54. Barrow, S._120

55. Barrow, S._122

56. Barrow, S._124

57. Bofra, P._1382

58. Damborg, A. 418

59. Dransfield, J. 7543

60. Dransfield, J._ 7550

61. Dransfield, J. 7575

62. Dransfield, J. 7582

63. Dransfield, J. 7587

64. Dransfield, J. 7610

65. Essig, F.B. 55023

66. Frodin, D.G._2604

67. Frodin, D.G._3154

68. Frodin, D.G._3190

69. Heatubun, C.D._85

70. Heatubun, C.D._87

71. Heatubun, C.D._91

72. Heatubun, C.D._92

73. Heatubun, C.D. -93

74. Heatubun, C.D. 97

75. Heatubun, C.D. 100

76. Heatubun, C.D. 110

77. Heatubun, C.D._123

78. Heatubun, C.D. 128

79. Heatubun, C.D._137

80. Heatubun, C.D._192

81. Heatubun, C.D._406

82. Heatubun, C.D._408

83. Heatubun, C.D._410

84. Heatubun, C.D. 415

85. Heatubun, C.D._416

86. Heatubun, C.D. 417

87. Heatubun, C.D. 418

88. Heatubun, C.D. 426

89. Heatubun, C.D. 531

90. Heatubun, C.D. 532

91. Heatubun, C.D._533

92. Heatubun, C.D. 538

93. Heatubun, C.D. 570

94. Heatubun, C.D. 746

95. Heatubun, C.D._747

96. Heatubun, C.D. 767

97. Heatubun, C.D. 776

98. Heatubun, C.D. 796

99. Heatubun, C.D. 798

100. Heatubun, C.D._799
101. Heatubun, C.D. 869

102. Heatubun, C.D. 870

103. Heatubun, C.D._871

104. Heatubun, C.D._876

105. Heatubun, C.D._969

106. Heatubun, C.D. 1038

107. Heatubun, C.D._1339

108. Heatubun, C.D._1342

109. Keim, A.P. 43

110. Maturbongs, R.A._282

111. Maturbongs, R.A._289

112. Maturbongs, R.A. 301

113. Maturbongs, R.A._308

114. Maturbongs, R.A._501

115. Maturbongs, R.A._502

116. Maturbongs, R.A._641

117. Maturbongs, R.A._662

118. Milliken, W._1193

119. Milliken, W._1423

120. Milliken, W._1434

121. Milliken, W._1435

122. Milliken, W._1469

123. Milliken, W._1544

124. Morren, G. 223

125. Morren, G._2911

126. Morren, G._2941

127. Morren, G._2945

128. Morren, G._2962

129. Morren, G._3041

130. Morren, G._3047

131. Morren, G. 3049

132. Morren, G._3059

133. Poudyal_54

134. Sagisolo, M._680

135. Schodde, R._ 2248

136. Simbiak, V.I._138

137. Zieck, J.F.U. 36175

138. Zieck, J.F.U. 36182

139. Zieck, J.F.U._36215

140. Zieck, J.F.U._36525 